\title{
COMMENTS
}

\section{Collateral Attacks on Employment Discrimination Consent Decrees}

Employment discrimination lawsuits often affect the interests of employees who are not parties to the lawsuits. Those nonparty effects may be especially pronounced when minority plaintiffs and their employer negotiate a consent decree establishing quotas for the hiring or promotion of minorities. ${ }^{1}$ In such cases, the nonparty "majority" employees can attempt to intervene in the original action to protect their interests. However, if the majority employees are unable to intervene, their only alternative is to bring a subsequent suit against the employer alleging that the remedies contained in the consent decree are themselves unlawful. ${ }^{2}$

1 These cases are typically brought as class actions under Title VII of the Civil Rights Act of 1964, Pub. L. No. 88-352, $\S$ 701-716, 78 Stat. 253 (codified as amended at 42 U.S.C. $\S 2000 \mathrm{e}$ to $\S 2000 \mathrm{e}-17$ (1982)) [hereinafter cited as Title VII]. However, some are brought under other statutes, such as 42 U.S.C. $\$ 1981$ (1982) or 42 U.S.C. $\$ 1983$ (1982).

A consent decree is a negotiated settlement which is entered as a judgment of the court, see United States v. City of Miami, 664 F.2d 435, 439 (5th Cir. 1981) (en banc) (Rubin, J., concurring), and which can have res judicata effect, see infra note 35 . When the court enters the decree, it does not resolve the merits of the underlying dispute, see City of Miami, 664 F.2d at 440 (Rubin, J., concurring), although it may conduct a more limited inquiry into the propriety of the decree, see infra note 25 .

2 Throughout this comment the term "employees" refers both to persons who are currently working for an employer and to job applicants, except where the distinction is of particular relevance. The initial suit brought against the employer is referred to as the "original" action; the plaintiffs in that suit are described as "minority" employees. Later suits that challenge the consent decree entered in the original suit are referred to as "subsequent" suits; the plaintiffs in those suits are described as "majority" employees.

The use of the terms "minority" and "majority" in this context, however, is somewhat imprecise. While most original suits are brought by blacks, women, or members of other groups commonly referred to as minorities, such suits can also be brought by white males. See McDonald v. Santa Fe Trail Transp. Co., 427 U.S. 273, 280 (1976).

In addition, in certain cases, either the Equal Employment Opportunity Commission (EEOC) or the Attorney General of the United States can sue on behalf of minority employees. See Title VII § 706(f)(1), 42 U.S.C. § 2000e-5(f)(1) (1982) (EEOC may bring suits against private employers; Attorney General may bring suits against state and local government employers). The analysis in this comment is the same whether suit is brought by minority employees, or by the EEOC or the Attorney General. 
These subsequent suits have several undesirable features. First, they duplicate much of the effort involved in the original suit. Second, they delay a final resolution of the contested situation. Third, they may result in judgments inconsistent with the terms of the original consent decree. Fourth, they may undercut a statutory policy favoring the resolution of employment discrimination disputes through settlement.

Several courts have refused to consider subsequent suits on the merits. Labeling them "impermissible collateral attacks" on the consent decree, ${ }^{3}$ these courts have dismissed subsequent suits for lack of subject-matter jurisdiction. However, other courts would allow subsequent suits, reasoning that majority employees must be permitted to advance their substantive arguments unless they are barred under accepted principles of res judicata or comity among federal courts.

This comment examines whether federal courts should reach the merits of subsequent suits brought by majority employees. Part I discusses the cases establishing the "impermissible collateral attack" rule. Part II identifies the possible grounds that might require dismissal of such suits, and finds that none is satisfactory. The comment thus concludes that federal courts should reach the merits of the majority employees' claims. Part III then examines various ways to minimize the costs posed by subsequent suits and demonstrates that the threatened costs need not materialize: courts can limit the issues heard in subsequent suits, and if majority employees are joined as parties or are allowed to intervene in the original action, later suits can be precluded altogether under established principles of res judicata.

\section{The "Impermissible Collateral AtTack" Cases}

A line of four decisions has developed a rule that subsequent suits by majority employees should always be dismissed as "impermissible collateral attacks" on the judgment in the original action.

${ }^{3}$ Prate v. Freedman, 430 F. Supp. 1373, 1375 (W.D.N.Y.), aff'd mem., 573 F.2d 1294 (2d Cir. 1977), cert. denied, 436 U.S. 922 (1978).

4 The cases are O'Burn v. Shapp, 70 F.R.D. 549 (E.D. Pa.), aff'd mem., 546 F.2d 417 (3d Cir. 1976), cert. denied, 430 U.S. 968 (1977), Prate v. Freedman, 430 F. Supp. 1373, 1375 (W.D.N.Y.), aff'd mem., 573 F.2d 1295 (2d Cir. 1977), cert. denied, 436 U.S. 922 (1978), Dennison v. City of Los Angeles Dep't of Water \& Power, 658 F.2d 694 (9th Cir. 1981), and Thaggard v. City of Jackson, 687 F.2d 66 (5th Cir. 1982), cert. denied sub nom. Ashley v. City of Jackson, 464 U.S. 900 (1983). These cases, hereinafter referred to collectively as the Thaggard cases, share certain facts. In each, minority employees filed a class action alleging that their employer had discriminated against them in violation of Title VII or other law. 
This rule is based entirely on procedural grounds, rather than on substantive employment discrimination law. Although other courts have considered subsequent suits on the merits and have concluded that they do not state a good claim under Title VII or other law, ${ }^{5}$ the courts in these four cases never got that far.

In the earliest case, O'Burn $v$. Shapp, ${ }^{6}$ majority employees and applicants argued that due process required that their suit be considered on the merits, since they had not been parties to the original action. ${ }^{7}$ Rejecting this argument, the district court responded that "an unqualified right to collaterally relitigate the merits" of a decree belongs only to "a stranger to a prior suit, who lacks any opportunity to timely contest the validity of the final judgment rendered in that prior suit."8 Since the court in which the original action was filed continued to maintain jurisdiction over the consent decree, the majority employees and applicants could still contest the decree by attempting to intervene in the original action. Thus, the district court dismissed their subsequent suit. ${ }^{9}$

The second case, Prate $v$. Freedman, ${ }^{10}$ involved a challenge to a consent decree establishing preferential procedures for hiring nonwhite police officers. Unlike the majority employees and applicants in $O^{\prime} B u r n$, the Prate plaintiffs had already sought to intervene in the original action, but since their request came more than a year after entry of the consent decree, it was denied as un-

The parties then negotiated a consent decree requiring that a certain percentage of positions be filled with members of the plaintiffs' class. See, e.g., Thaggard, 687 F.2d at 67 (consent decree provided that black and white employees were to be promoted in a "one-to-one ratio until the proportion of black persons in supervisory positions and in the ranks of patrolmen substantially equalled the proportion of blacks to whites in the City of Jackson"). Subsequently, majority employees who were not parties to the original action brought separate suits contending that the employer, by complying with the terms of the consent decree, had engaged in "reverse discrimination." These suits sought injunctive relief, compensatory relief, or both. See infra notes 15-16 and accompanying text.

- See, e.g., Dennison v. City of Los Angeles Dep't of Water \& Power, 21 Fair Empl. Prac. Cas. (BNA) 1120, 1122-23 (C.D. Cal. 1979), aff'd on other grounds, 658 F.2d 694 (9th Cir. 1981); see also EEOC v. McCall Printing Corp., 633 F.2d 1232, 1238 (6th Cir. 1980) (considering the merits of a collateral challenge to a consent decree that provided retroactive seniority for some employees).

- 70 F.R.D. 549 (E.D. Pa.), aff'd mem., 546 F.2d 418 (3d Cir. 1976), cert. denied, 430 U.S. 968 (1977).

7 Id. at 552.

Id.

- Id. at 553. The court based its dismissal on a lack of subject-matter jurisdiction. See Fed. R. Civ. P. 12(b)(1).

${ }^{10} 430$ F. Supp. 1373 (W.D.N.Y.), aff'd mem., 573 F.2d 1294 (2d Cir. 1977), cert. denied, 436 U.S. 922 (1978). 
timely. ${ }^{11}$ Thus, a separate suit offered the only remaining opportunity for them to contest the decree. Nonetheless, the court dismissed their subsequent suit, noting that they "should properly have sought timely intervention in the [original] case, but failed to do so."12 In support of its decision, the court argued that allowing the challenge would "clearly violate the policy under Title VII to promote settlement ...., would also result in continued uncertainty for all parties involved and [would] render the concept of final judgments meaningless."13

In Dennison v. City of Los Angeles Department of Water \& Power, ${ }^{14}$ majority employees attempted to avoid the rule of $O^{\prime} B u r n$ and Prate by seeking compensatory damages rather than injunctive relief. ${ }^{15}$ The Ninth Circuit rejected the distinction. ${ }^{16}$ Contending that subsequent actions were "inimical to the policy underlying Title VII of promoting settlements" and could subject the employer to inconsistent obligations, the court followed the "settled" rule "that a consent decree is not subject to collateral attack."17

Finally, in Thaggard $v$. City of Jackson, ${ }^{18}$ the Fifth Circuit confronted a situation much like that in Prate: the majority employees had tried unsuccessfully to intervene in the original suit, so that a separate action was their only remaining option. Citing the "settled" rule of Dennison and the policy concerns of Prate, the

11 Id. at 1374. The requirement that a request to intervene be "timely" is imposed by rule 24 of the Federal Rules of Civil Procedure. See infra notes 52-53 and accompanying text.

12430 F. Supp. at 1375 (emphasis added).

13 Id. (citations omitted).

14658 F.2d 694 (9th Cir. 1981).

${ }^{16}$ In $O^{\prime} B u r n$, the majority employees sued for an injunction. See 70 F.R.D. at 551. In Prate, the majority employees sought both compensatory damages and an injunction. See 430 F. Supp. at 1374.

${ }^{16}$ Dennison, 658 F.2d at 695 (compensation granted in a subsequent suit "would drastically increase the cost of each promotion and would burden [the defendant employer] for complying with the consent decree"). The Ninth Circuit thus rejected the approach taken in McAleer v. American Tel. \& Tel. Co., 416 F. Supp. 435 (D.D.C. 1976). McAleer involved a subsequent suit brought by a majority employee entitled to a promotion under a collective bargaining agreement who was denied the promotion because of a quota established by a consent decree. Id. at 436-37. While the court refused to order the employer to promote the plaintiff, it held that the plaintiff was entitled to damages. Id. at 439-41; see also id. at 438 (court refused to consider majority employee's direct challenge to quota's validity).

17 Dennison, 658 F.2d at 695-96. The Ninth Circuit also deemed it fair to dismiss the subsequent suit because the lower court had, before entering the consent decree, held a hearing in which the union representing the majority employees was allowed to participate and raise objections to the decree. Id. at 696. For a criticism of that reasoning, see infra note 50 .

${ }^{18} 687$ F.2d 66 (5th Cir. 1982), cert. denied sub nom. Ashley v. City of Jackson, 464 U.S. 900 (1983). 
court affirmed a dismissal based on lack of subject-matter jurisdiction. ${ }^{19}$ The court refused to consider whether the plaintiffs should have been allowed to intervene in the original action. ${ }^{20}$

While the majority of courts considering the issue have accepted this rule barring collateral attacks on consent decrees, ${ }^{21}$ some courts and individual judges either have explicitly rejected it or have indirectly suggested that they would reject it. ${ }^{22}$ Most nota-

19 Id. at 68. The court also rejected the majority employees' argument that their suit was not a collateral attack since it was based on actions of the employer which allegedly contravened the decrees: "[P]laintiffs' position necessitates a decision regarding precisely what activity is mandated by the decrees' requirement that defendants 'seek to achieve' certain goals. . . . [However, i]mplementation of and continued compliance with the consent decrees is under the supervision of the district court that entered the decrees." Id. (footnote omitted).

${ }^{20}$ Id. at 69 . The Fifth Circuit subsequently affirmed the trial court's decision denying intervention. See Corley v. Jackson Police Dep't, 755 F.2d 1207, 1210 (5th Cir. 1985).

${ }^{21}$ In addition to the Ninth Circuit (in Dennison) and the Fifth Circuit (in Thaggard, but see infra note 22), a number of other circuits either have adopted the Thaggard rule, or have taken similar approaches. The First Circuit endorsed the rule in dicta in Culbreath v. Dukakis, 630 F.2d 15, 22 (1st Cir. 1980). The Seventh Circuit endorsed it in Grann v. City of Madison, $738 \mathrm{~F} .2 \mathrm{~d} 786,796$ (7th Cir.) (where the employer promoted minority employees in response to a state agency's order, the court saw "no more reason to permit a collateral attack on the agency's order than we do to permit a collateral attack on a consent decree"), cert. denied, $105 \mathrm{~S}$. C $t_{t} .296$ (1984), although the court seemed also to base dismissal on substantive Title VII law, see 738 F.2d at 794 ("the only rational resolution of the issue posed by plaintiffs is to hold that reliance on a state agency's order . . . is an absolute bar to a suit by fellow employees"). The Sixth Circuit relied on a somewhat confused mix of substantive and procedural grounds to conclude that "reverse discrimination challenges to reasonable consent decrees are impermissible collateral attacks." Stotts v. Memphis Fire Dep't, 679 F.2d 541, 558 (6th Cir. 1982), rev'd on other grounds sub nom. Firefighters Local Union No. 1784 v. Stotts, 467 U.S. 561, 104 S. Ct. 2576 (1984). But cf. EEOC v. McCall Printing Corp., 633 F.2d 1232, 1238 (6th Cir. 1980) (reaching the merits of a collateral challenge to a consent decree that granted retroactive seniority to some employees). The Fourth Circuit appeared to take an approach similar to Thaggard in Goins v. Bethlehem Steel Corp., 657 F.2d 62 (4th Cir. 1981), cert. denied, 455 U.S. 940 (1982). However, the decision is somewhat ambiguous since it does not expressly identify the plaintiffs who brought the subsequent suit, leaving open the possibility that they were members of the plaintiff class in the original action and therefore bound by its result under res judicata. Lastly, the Third Circuit's approach to a case outside the employment discrimination context suggests that it would adopt an approach similar to Thaggard. See Society Hill Civic Ass'n v. Harris, 632 F.2d $1045,1050-52$ (3d Cir. 1980) ("We . . . agree that an unjustified or unreasonable failure to intervene [in the original action] can serve to bar a later collateral attack.").

Some lower courts either have endorsed the Thaggard approach, see, e.g., Austin v. County of DeKalb, 572 F. Supp. 479, 481 (N.D. Ga. 1983), or have suggested that it has some merit, see, e.g., Cuesta v. New York Office of Court Admin., 571 F. Supp. 392, 395-96 (S.D.N.Y. 1983).

${ }^{22}$ See Ashley v. City of Jackson, 464 U.S. 900 (1983) (Rehnquist, J., dissenting from denial of certiorari); United States v. Jefferson County, 720 F.2d 1511, 1518 \& n.20 (11th Cir. 1983) (discussed infra at note 26); Reeves v. Wilkes, 754 F.2d 965, 969-72 (11th Cir. 1985) (adhering to the rule adopted in Jefferson County); Johnson v. North Carolina State Highway Patrol, 91 F.R.D. 406, 408 (E.D.N.C. 1980); Harmon v. San Diego County, 477 F. 
bly, Justice Rehnquist, joined by Justice Brennan in dissenting from the denial of certiorari in Thaggard, characterized that case as presenting "the question [of] whether a victim of alleged discrimination may have his right to sue totally extinguished by a prior suit to which he was not a party and in which a consent decree was entered before his cause of action even accrued."23 Justice Rehnquist argued that under established principles of res judicata and due process, the subsequent suit should be allowed to proceed as long as the plaintiff was "not a party nor a privy" to the original litigation. ${ }^{24} \mathrm{He}$ contended that due process concerns are particularly strong when the judgment given preclusive effect is a consent decree, which "is little more than a contract between the parties, formalized by the signature of a judge."25 Finally, Justice Rehn-

Supp. 1084, 1091 (S.D. Cal. 1979), aff'd in part and rev'd in part on other grounds, 664 F.2d 770 (9th Cir. 1981); Bacica v. Board of Educ., 451 F. Supp. 882, 886 (W.D. Pa. 1978) (consent decree entered in state court suit does not preclude subsequent federal court suit brought by nonparty majority employees).

In addition, one panel of the Fifth Circuit has expressed second thoughts about the holding in Thaggard. In Corley v. Jackson Police Dep't, 755 F.2d 1207 (5th Cir. 1985), that panel affirmed the Thaggard trial court's refusal to allow majority employees to intervene in the original suit. But the panel observed:

[If] well-settled intervention rules in combination with the rule of Thaggard $v$. City of Jackson, to which we are firmly bound here, unjustly deny a party his day in court, then the appropriate remedy lies in reexamination of the Thaggard doctrine in the appropriate forum, particularly in light of the persuasive opinion of Justice Rehnquist, joined in by Justice Brennan, dissenting from the denial of certiorari in Thaggard ....

Id. at 1210.

${ }^{23}$ Ashley, 464 U.S. at 900.

${ }^{24}$ Id. at 902 (quoting Parklane Hosiery Co. v. Shore, 439 U.S. 322, 327 n.7 (1979)). "Privity" is a shorthand term used to describe several narrow exceptions to the general rule that a judgment cannot preclude subsequent litigation by persons who were not parties to the judgment. See infra note 41 and accompanying text.

${ }^{28}$ Ashley, 464 U.S. at 902 . When a court enters a consent decree, it does not resolve the merits of the underlying dispute. See supra note 1. Beyond that, there is considerable variation in the extent to which courts will attempt to inquire into the propriety of the decree. Some consent decrees are "rubber stamped" by the entering court. For example, in cases where the federal government brings suit on behalf of minority employees, courts often enter a decree on the same day that the complaint is filed. See Schwarzschild, Public Law by Private Bargain: Title VII Consent Decrees and the Fairness of Negotiated Institutional Reform, 1984 Duke L.J. 887, 913. However, some courts assert that the decree should be "examine[d] carefully" to ensure that it is a fair resolution of the dispute and does not violate "Constitution, statute, or jurisprudence." United States v. City of Miami, 664 F.2d 435, 441 (5th Cir. 1981) (en banc) (Rubin, J., concurring). Furthermore, when the decree settles a class action, courts should hold hearings-sometimes referred to as "fairness hearings"-to consider any substantial objections to the decree raised by members of the plaintiff class. See, e.g., Mandujano v. Basic Vegetable Prods., Inc., 541 F.2d 832, 835-36 (9th Cir. 1976); Schwarzschild, supra, at 914-15; see also FED. R. Crv. P. 23(e) (requiring court approval of proposed settlements of class actions; also requiring that class members be given notice of proposed settlements). A few courts have invited majority employees to ap- 
quist suggested that while compliance with a decree might give rise to a "good faith" defense, it should not block suit altogether. ${ }^{26}$

\section{The Duty to Hear Collateral Attacks by MajoRITy EMpLOYEeS}

In dismissing the subsequent suits of majority employees, the courts in the line of cases which culminated in Thaggard have drawn upon three distinct sources of authority. One is the doctrine of res judicata, under which litigation can be precluded if an earlier matter involving the same or similar subject matter has already proceeded to judgment. ${ }^{27}$ Another is the principle of comity, which allows courts, in their discretion, to decline to exercise jurisdiction over a suit if an action involving the same or similar subject matter is pending before another court. ${ }^{28}$ And a third is Title VII itself: subsequent suits could undercut a congressional policy favoring the voluntary resolution of employment discrimination disputes. ${ }^{29}$

Although the Thaggard courts have looked to each of these sources of authority, they have done so haphazardly and with little explanation. Most notably, they do not clearly distinguish between res judicata and comity. They have frequently addressed the issues posed by subsequent suits in res judicata terms: they have expressed concern about preserving the finality of judgments, and

pear at such hearings, although the practice does not appear to be widespread. See supra note 17 (discussing the hearing held by the original court in Dennison); Schwarzschild, supra, at 919.

${ }^{28}$ Ashley, 464 U.S. at 903 . In United States v. Jefferson County, 720 F.2d 1511 (11th Cir. 1983), the Eleventh Circuit concluded that the res judicata and due process principles identified by Justice Rehnquist governed the question of whether majority employees could bring a subsequent suit. Id. at 1517-18, 1519 n.20 (Res judicata "prevent[s] the attack of a prior judgment by parties to the proceedings or by those with sufficient identity of interests with such parties that their interests are deemed to have been litigated in those proceedings. A final judgment may not, however, bind a nonparty when his interests were not represented."). It then discussed the issues it envisioned arising in such a suit. First, it observed that if "the employer undertook the challenged action pursuant to a court-approved consent decree [this] would be evidence of nondiscriminatory intent by the employer, and the nonparty could not seek to relitigate the merits or reasonableness of the decree vis-a-vis the parties to the decree." Id. at 1518 (citation omitted). The court added that if the employer offered its compliance with the consent decree as a defense to the majority employees' claims, "the trial judge would have to determine whether the defendant's action was mandated by the decree and, if so, whether that fact alone would relieve the defendant of liability that would otherwise attach." Id. The court did not suggest how the latter question should be answered.

${ }^{27} \mathrm{See}^{2}$ infra notes 33-71 and accompanying text.

${ }^{28}$ See infra notes 72-86 and accompanying text.

20 See infra notes 87-111 and accompanying text. 
have invoked principles and terms developed in res judicata cases. ${ }^{30}$ But they ultimately have dismissed on grounds of lack of subject-matter jurisdiction, ${ }^{31}$. a disposition more consistent with the comity notion that, as long as a court's consent decree remains in effect, only that court has jurisdiction to consider disputes arising from the decree's operation. ${ }^{32}$

This section examines each of the rationales underlying the Thaggard line of decisions. It first considers whether it is consistent with due process for courts to apply principles of res judicata to bind majority employees to the judgment entered in the original action. Then it examines whether the dismissal of subsequent suits accords with the principles of comity. Finally, it evaluates the contention that subsequent suits frustrate Title VII's policy of promoting settlements.

\section{A. Res Judicata and the Requirements of Due Process}

The Thaggard courts have rested their dismissals of subsequent suits in large part on principles of res judicata. In general,

${ }^{30}$ For example, the Thaggard courts have argued that it is fair to dismiss subsequent suits by majority employees because those employees had an opportunity to intervene in the original action, see, e.g., Dennison, 658 F.2d at 696; Prate, 430 F. Supp. at 1375, an argument with roots in the case law on res judicata, see infra notes $44-49$ and accompanying text. They also describe subsequent suits by majority employees as constituting "impermissible collateral attack[s]" that would undermine the finality of judgments entered in the original actions. Prate, $430 \mathrm{~F}$. Supp. at 1375 . Outside the employment discrimination context, "impermissible collateral attack" appears to be a term of art used to describe suits precluded under principles of res judicata. See, e.g., Miller v. Meinhard-Commercial Corp., 462 F.2d 358, 360 (5th Cir. 1972) ("[T]he confirmation of the arrangement by the referee was proper and its effect is res judicata to the claim raised in this suit . . . The suit is no more than a collateral attack upon the referee's order."); 1B J. MOORE, J. LuCAS \& T. CuRRIEr, Moore's Federal Practice II .405[4.-1], at 198-99 (1984); id. II .407, at 287.

${ }^{31}$ See, e.g., Thaggard, 687 F.2d at 69; Prate, 430 F. Supp. at 1375; O'Burn, 70 F.R.D. at 553. The courts dismiss on this ground under rule 12(b)(1) of the Federal Rules of Civil Procedure. In contrast, res judicata is an affirmative defense which must be pleaded under rule 8 (c), and proved by the party asserting it. See 18 C. WRIGHT, A. MiLLER \& E. Cooper, Federal Practice and Procedure § 4405 (1981).

The Thaggard courts' reliance on rule 12(b)(1) to dismiss subsequent suits because of the pendency of another action is a somewhat unusual use of the rule, for which there is no close parallel outside the employment discrimination context. See 5 C. WRIGHT \& A. MrLLER, Federal Practice and Procedure § 1350 (1969); cf. infra note 76 and accompanying text (discussing a court's inherent power to stay or dismiss suits on comity grounds).

${ }^{32}$ See O'Burn, 70 F.R.D. at 553. The court in O'Burn emphasized the fact that the original court had explicitly retained jurisdiction over the decree. Id. at 552-53. Nevertheless, the comity analysis does not depend on an explicit retention of jurisdiction, since the original court would in any event have authority to modify the decree. See United States v. Swift \& Co., 286 U.S. 106, 114-15 (1932);-Lapin v. Shulton, Inc., 333 F.2d 169, 170 (9th Cir.), cert. denied, 379 U.S. 904 (1964). 
those principles are used to determine whether a prior judgment can serve as the basis for precluding subsequent litigation. The doctrine of res judicata thus helps to avoid duplication of effort and inconsistent judgments, and ensures that disputes can be resolved with some finality. ${ }^{33}$

Prior judgments may prevent subsequent litigation in two ways: through claim preclusion and through issue preclusion. Under claim preclusion, the assertion of a claim in a suit that results in a valid final judgment bars subsequent actions on the same claim, whether or not all the grounds that could have been advanced to support the claim were actually presented in the original action. ${ }^{34}$ Under issue preclusion, the resolution of an issue in the original suit is binding in subsequent litigation if the issue was actually litigated and its resolution was essential to the original judgment. $^{35}$

There is considerable tension between these res judicata rules and the requirements of fifth and fourteenth amendment due process; indeed, to a large extent the latter determine the limits of the former. ${ }^{36}$ One central due process principle was articulated by the Supreme Court in Mullane v. Central Hanover Bank \& Trust Co. ${ }^{37}$ Mullane involved a statute that established a procedure for considering claims by trust beneficiaries against their trustee. Under the statute, notice of judicial proceedings to adjudicate such claims was to be published in a local newspaper; the claims of any beneficiaries who failed to participate were to be extinguished. The Court held that the statute violated due process because it provided the beneficiaries with insufficient notice of the opportunity to present their claims. According to the Court, "[a]n elementary and fundamental requirement of due process in any proceeding

33 See 18 WRIGHT, MILLER \& CoOPER, supra note $31, \S 4403$ (res judicata prevents the “corrosive disrespect" which would result from inconsistent judgments, preserves judicial resources, and provides repose for the original parties).

34 Id. $\S 4406$. For an elaboration of the definition provided in the text, see id. $\S \S 4406-$ 4415; Restatement (Second) OF JudGMENTS $\$ \$ 18-26$ (1980).

ss Restatzment (Second) of Judgments $\$ 27$ (1980). For an elaboration of the definition provided in the text, see $i d$. $\S 28$; 18 WRIGHT, MnLER \& CoOPER, supra note 31 , $\S 4416$ 4426. The requirement that an issue be "actually litigated" means that consent judgments cannot have issue preclusive effect in subsequent litigation, since a court which enters a consent judgment does not resolve the issues which underlie the dispute. See supra notes 1, 25. However, consent judgments can have claim preclusive effect. See 18 WRIGHT, MILLER \& COOPER, supra note 31 , § 4443.

${ }^{36}$ See Restatement (Second) of Judgments 6-7 (1980). This comment will use the phrase "due process" to refer to the due process clauses of both the fifth and the fourteenth amendments.

33 U.S. 306 (1950). 
which is to be accorded finality is notice reasonably calculated, under all the circumstances, to apprise interested parties of the pendency of the action and afford them an opportunity to present their objections." 38

The Mullane requirement of notice and an opportunity to be heard sharply limits the extent to which principles of res judicata can be used to preclude suits by persons who were not parties to the original action. ${ }^{38}$ Indeed, "[ $\left.t\right]$ he basic premise of preclusion is that parties to a prior action are bound and nonparties are not bound." 40 Yet there are some circumstances in which preclusion of a nonparty is considered acceptable. ${ }^{41}$ One occurs when the nonparty controlled a party's conduct of the original litigation to such an extent that the nonparty can fairly be treated as though he had been a party. ${ }^{42}$ Another occurs when the nonparty's interests were adequately represented by a party in the original litigation. ${ }^{43}$

${ }^{38}$ Id. at 314.

38 See 18 WrIGHT, Miller \& CoOPER, supra note 31 , § 4449, at 415.

so Id. at 411 .

4 Nonparties who can be precluded are often described as having been in "privity" with a party. See id., $\S 4449$, at $418-19$.

12 See Restatement (Second) of Judgments $\S 39$ (1980); 18 Wright, Miller \& COOPER, supra note $31, \S 4451$. However, "it is not enough that the nonparty supplied an attorney or is represented by the same law firm; helped to finance the litigation; appeared as an amicus curiae; testified as a witness; participated in consolidated pretrial proceedings; undertook some limited presentations to the court; or otherwise participated in a limited way." Id. \& 4451, at 432-33 (footnotes omitted); see REstatement (SECOND) of JuDGMENTs $\$ 39$ comment c (1980). But such acts may be evidence of control. See Montana v. United States, 440 U.S. 147, 155 (1979).

This theory of nonparty preclusion-which will be referred to here as de facto participation-has on occasion been applied to majority employees in the employment discrimination context. See, e.g., Bolden v. Pennsylvania State Police, 578 F.2d 912, 915-18 (3d Cir. 1978). However, for two reasons it probably cannot be used to preclude suits that challenge consent decrees. First, consent decrees generally cannot have issue preclusive effect in subsequent litigation. See supra note 35. In addition, de facto participation cannot lead to claim preclusion, because "the person controlling the litigation, as a non-party, is by definition asserting or defending a claim other than the one he himself may have." RESTATEMENT (SECOND) of Judgments $\$ 39$ comment b (1980); see also Montana v. United States, 440 U.S. at 154 .

43 See 18 Wright, MrLLER \& CoOpER, supra note 31, $\$ 4454$, at 459. This theory of nonparty preclusion-which will be referred to here as adequate representation-has its roots in a few limited classes of relationships, involving, for example, "[t]rustees, executors, statutory representatives in death and survival actions, and guardians." Id. § 4448, at 409. However, the theory has also been applied to class actions, see Hansberry v. Lee, 311 U.S. 32 (1940); 18 WRIGHT, Miller \& CoOPER, supra note 31, § 4455; REstatement (SECOND) OF JUDGMENTS $\S 41(1)(e)$ \& comment e (1980), and to litigation undertaken by collective bargaining representatives, see 18 Wright, MinLER \& CoOPER, supra note 31 , $\$ 4456$; REstateMENT (SECOND) of JudGMENTS § 61 (1980); see also Telephone Workers Union v. New Jersey Bell Tel. Co., 584 F.2d 31, 33-34 (3d Cir. 1978). Hansberry is the leading modern case considering the limits that due process places on the theory of adequate representation. As 
Some courts and commentators have attempted to develop a third category of nonparty preclusion: "mandatory intervention." 44 Under mandatory intervention, a person who passes up an opportunity to intervene in an action can be bound by its result. The Supreme Court in 1934 expressed disapproval of a rule of mandatory intervention: "The law does not impose upon any person absolutely entitled to a hearing the burden of voluntary intervention in a suit to which he is a stranger."45 However, in the late 1960s some movement occurred in the Court's position. In the Penn-Central Merger and $N \& W$ Inclusion Cases, ${ }^{46}$ the Court held that when a number of persons brought separate suits challenging a single administrative order and all but one of those suits were stayed, those persons who then failed to intervene in the remaining suit were bound by its result.47 The Court's holding may be restricted to the facts of that case; ${ }^{48}$ nevertheless, a short time

interpreted by subsequent cases, Hansberry imposes a two-prong due process requirement: (1) the interests of the nonparty must have been aligned with those of the party; and (2) the party must in fact have done an adequate job of representing those interests. See 311 U.S. at 41.43; Gonzales v. Cassidy, 474 F.2d 67, 74-75 (5th Cir. 1973); 18 WRIGHT, MrLLER \& COOPER, supra note $31, \S 4455$, at $478-82$.

Some courts and commentators have sought to extend the adequate representation theory beyond these established contexts to any case in which the minimum due process requirements of Hansberry are met. See, e.g., Aerojet-General Corp. v. Askew, 511 F.2d 710, 719-20 (5th Cir.), cert. denied and appeal dismissed, 423 U.S. 908 (1975); Cauefield v. Fidelity \& Casualty Co., 378 F.2d 876, 878-79 (5th Cir.), cert. denied, 389 U.S. 1009 (1967); 18 WrIGHT, MiLler \& COOPER, supra note 31, § 4457, at 494; Vestal, Res Judicata/Preclusion: Expansion, 47 S. CAI. L. REv. 357, 378-81 (1974). However, this extension of the theory has not been broadly accepted, and even the courts that invoke the theory outside its traditional contexts typically do so only in cases where other theories of preclusion are also applicable. See 18 Wright, MILLER \& CoOPER, supra note $31, \S 4457$, at 495-99.

The Third Circuit appeared to attempt such an extension of the adequate representation theory in Bolden v. Pennsylvania State Police, 578 F.2d 912, 918-19 (3d Cir. 1978), where it concluded that nonparty majority applicants were bound by a decree because their potential employer had adequately represented their interests in the original litigation. Few other courts have considered this possible application of the theory. See, e.g., Harmon v. San Diego County, 477 F. Supp. 1084, 1091 (S.D. Cal. 1979) (the employer "did not necessarily have interests identical to or parallel with those of its male white employees"), aff'd in part and rev'd in part on other grounds, 664 F.2d 770 (9th Cir. 1981).

4 See 18 WrIGHT, Miller \& CoOPER, supra note $31, \S 4452$.

4s Chase Nat'l Bank v. Norwalk, 291 U.S. 431, 441 (1934).

48 U.S. 486 (1968).

47 Id. at 505-06.

is The holding could be narrowed on two grounds. First, the Supreme Court had reviewed and affirmed much of the district court's decision in the suit which was not stayed. Id. Thus, the Court's pronouncement that the non-intervenors were bound can be interpreted as "simply stating the obvious fact that inferior courts may not reverse the Supreme Court or its rulings." Morris v. Gressette, 425 F. Supp. 331, 336-37 (D.S.C. 1976) (threejudge panel), aff'd on other grounds, 432 U.S. 491 (1977). Second, it could be interpreted as being "peculiar to multiple proceedings to review a single administrative order. There is a 
later, the Court suggested that the broader use of mandatory intervention remained an open question. ${ }^{49}$ ?

The courts in the Thaggard line of cases appear to rely primarily on a principle of mandatory intervention. ${ }^{50}$ To these courts,

great need for speed, and little reason to suppose that individual litigants should be protected against the burdens of litigating in inconvenient courts with unattractive allies." 18 Wright, Miller \& Cooper, supra note 31, § 4452, at 450; see McCoid, A Single Package for Multiparty Disputes, 28 Stan. L. Rev. 707, 719 (1976). But see Penn-Central Merger and $N \& W$ Inclusion Cases, 389 U.S. at 541-44 (Douglas, J., dissenting in part) (interpreting the majority opinion as "declar[ing] . . . a new rule of res judicata").

18 See Provident Tradesmens Bank \& Trust Co. v. Patterson, 390 U.S. 102, 114 (1968) ("II]t might be argued that Dutcher should be bound by the previous decision because, although technically a nonparty, he had purposely bypassed an adequate opportunity to intervene. We do not now decide whether such an argument would be correct under the circumstances of this case."). Since Provident Tradesmens, the majority of courts to consider mandatory intervention have rejected it. See, e.g., Consumers Union, Inc. v. Consumer Prod. Safety Comm'n, 590 F.2d 1209, 1216-19 (D.C. Cir. 1978), rev'd on other grounds sub nom. GTE Sylvania, Inc. v. Consumers Union, Inc., 445 U.S. 375 (1980); McGhee v. United States, 437 F.2d 995, 999-1000 (Ct. Cl. 1971); see also 18 WrIGHT, Miller \& CoOpER, supra note 31, § 4452, at 447-49 \& nn.15, 17-19; Note, Preclusion of Absent Disputants to Compel Intervention, 79 Colum. L. REv. 1551, 1562 \& n.77 (1979). However, a few courts have relied on mandatory intervention to preclude nonparties, although typically other theories of preclusion were also applicable in those cases. See, e.g., Treasure Salvors, Inc. v. Unidentified Wrecked and Abandoned Sailing Vessel, 459 F. Supp. 507, $512-18$ (S.D. Fla. 1978), aff'd on other grounds sub nom. Florida Dep't of State v. Treasure Salvors, Inc., 621 F.2d 1340 (5th Cir. 1980), aff'd in part and rev'd in part on other grounds, 458 U.S. 670 (1982); 18 WRIGHT, MILLER \& COOPER, supra note $31, \S 4452$, at 450-51 \& nn.26-27. Other courts have approved the use of mandatory intervention to preclude nonparties in certain limited contexts. See, e.g., Griffin v. Burns, 570 F.2d 1065, 1071 n.7 (1st Cir. 1978).

${ }^{50}$ See Thaggard, 687 F.2d at 68 (challenges to a decree should be made before the original court; the subsequent court will not consider whether the original court erred in denying intervention); Dennison, 658 F.2d at 696 (majority employees' subsequent suit is precluded since the union which represents them "had sufficient opportunity to intervene [in the original] suit prior to the entry of the consent decree"); Prate, 430 F. Supp. at 1375 (plaintiffs in the subsequent suit "should properly have sought timely intervention in the [original] case, but failed to do so"); O'Burn, 70 F.R.D. at 552-53 (the subsequent suit should be dismissed since plaintiffs can present their views by intervening in the original action).

The only one of those cases to invoke another theory of preclusion is Dennison. There the district court which considered the minority employees' original suit held a "Fairness Hearing to allow persons who had previously submitted written objections to the consent decree the opportunity to present orally their objections to the court." Dennison, 658 F.2d at 695; see also supra note 25 (discussing the use of such hearings). All employees received written notice of the hearing, and the union representing the majority employees appeared at the hearing and "criticized the adverse impact of the consent decree on non-minority employees." Id. In dismissing a subsequent suit brought by majority employees, the Ninth Circuit argued that "the Fairness Hearing . . . adequately afforded the union an opportunity to present to the court its view." Id. at 696 .

The Ninth Circuit thus appeared to be invoking something like the de facto participation theory of nonparty preclusion: the majority employees' union had participated informally in the original proceeding to such an extent that it was fair to preclude subsequent litigation by the employees or their union. However, under traditional interpretations of the 
majority employees can obtain a hearing on the merits of their claims only by intervening in the original action pursuant to rule 24 of the Federal Rules of Civil Procedure. ${ }^{51}$ If majority employees fail to intervene, or if their request to intervene is denied, they will be bound by the judgment and lose the right to assert any claims which should properly have been raised in the original action.

In effect, the Thaggard courts have concluded that intervention under rule 24 provides majority employees with a constitutionally adequate opportunity to assert their interests. However, that conclusion may be incorrect. Rule 24 does not require the parties to an action to notify would-be intervenors that the suit is pending. Instead, the rule puts the burden on nonparties to take the initiative, and further provides that nonparties' requests to intervene can be denied if they are not "timely." A number of

de facto participation theory, see supra note 42 , preclusion would not be appropriate on the facts of Dennison since there was no evidence that the majority employees' union exerted any control over the actual parties' conduct of the litigation. While the due process clause might permit an extension of the de facto participation theory beyond the theory's traditional scope, it is not clear whether it would permit an expansion as far as the Ninth Circuit appears to advocate. The answer to that question would lie in a careful consideration of several factors, including the nature of the majority employees' interests and the procedural rights available to them in the fairness hearing, see Mathews v. Eldridge, 424 U.S. 319, 33435 (1976), an inquiry which the Ninth Circuit did not even attempt.

s1 A possible variation on this procedure is suggested by the Dennison court's argument that majority employees could be bound by the result of the original suit because their union had participated in a "Fairness Hearing" held by the court in that suit. See supra note 50 . Presumably that argument could be coupled with the mandatory intervention principle to hold that majority employees are bound by the result of the original suit if they pass up an opportunity to participate in a fairness hearing held in the course of that suit. Such an approach might comport with due process. But see supra note 50; infra notes 52-67 and accompanying text. Yet courts probably lack the power to adopt it. See infra notes 68-71 and accompanying text.

s2 Rule 24 provides in relevant part:

(a) INTERVENTION OF Right. Upon timely application anyone shall be permitted to intervene in an action: ... (2) when the applicant claims an interest relating to the property or transaction which is the subject of the action and he is so situated that the disposition of the action may as a practical matter impair or impede his ability to protect that interest, unless the applicant's interest is adequately represented by the existing parties.

(b) Permissive Intervention. Upon timely application anyone may be permitted to intervene in an action: ... (2) when an applicant's claim or defense and the main action have a question of law or fact in common ... . . In exercising its discretion the court shall consider whether the intervention will unduly delay or prejudice the adjudication of the rights of the original parties.

FED. R. Civ. P. 24.

Both sections of the rule impose several requirements in addition to timeliness. Courts have occasionally relied on these other requirements in rejecting majority employees' motions to intervene. See, e.g., Johnson v. North Carolina State Highway Patrol, 91 F.R.D. 406, 407 (E.D.N.C. 1980) (request for intervention under rule 24(a)(2) denied because would-be 
courts have held that intervention can be denied as untimely when a potential intervenor "knew or should have known of the pendency" of the action from newspaper accounts or other informal means and failed to act promptly thereafter. ${ }^{53}$

The timeliness requirement of rule 24, taken together with the Thaggard courts' mandatory intervention procedure, means that majority employees can be precluded from bringing a subsequent suit even if the only notice they had of the original proceeding was provided by informal media accounts. This result conflicts with Mullane and other Supreme Court cases considering the due process limits on res judicata. The most obvious constitutional flaw arises from the content of the notice provided to majority employees. The Supreme Court considered the minimum requirements which the due process clause places on the content of notice in Memphis Light, Gas \& Water Division v. Craft. ${ }^{54}$ There, a municipal utility repeatedly shut off the plaintiffs' utility service for alleged nonpayment. Before shutting off the service, the utility had mailed notices to the plaintiffs which stated only that the service would be discontinued if payment was not made by a certain date. The Court held that the termination of service violated due process, since the notices did not advise the plaintiffs of a procedure for contesting their bills. ${ }^{\mathrm{sb}}$ According to the Court, " $[t]$ he purpose of notice under the Due Process Clause is to apprise the affected individual of, and permit adequate preparation for, an impending

intervenor lacked sufficient interest in the subject matter); cf. Howard v. McLucas, $597 \mathrm{~F}$. Supp. 1501, 1502-03 (M.D. Ga. 1984) (proposed consent decree would have such a small impact on majority employees' interests that they "lack standing" to intervene). However, the timeliness requirement appears to have been the most prevalent ground for denying majority employees' motions to intervene. See infra note 53 (citing cases).

s3 NAACP v. New York, 413 U.S. 345, 366-67 (1973). Noting that the question of timeliness "is to be determined from all the circumstances," $i d$. at 366 , the Court also based its determination on other factors such as the absence of "unusual circumstances" which might warrant late intervention, id. at 368. Building on the Supreme Court's "all the circumstances" approach, lower courts have fashioned multi-factor tests to evaluate timeliness. See, e.g., Stallworth v. Monsanto Co., 558 F.2d 257, 264-66 (5th Cir. 1977). Thus, in addition to considering when the would-be intervenor should have known of the action, some courts also take into account factors such as the "prejudice" which the original parties would suffer if intervention is allowed. See, e.g., Culbreath v. Dukakis, 630 F.2d 15, 21-22 (1st Cir. 1980). A court's timeliness determination will be overturned only if it is found to be an abuse of discretion. NAACP, 413 U.S. at 366.

For cases denying intervention to majority employees on timeliness grounds, see Reeves v. Wilkes, 754 F.2d 965, 969-70 \& n.2 (11th Cir. 1985); Stotts v. Memphis Fire Dep't, 679 F.2d 579, 583 (6th Cir.), cert. denied sub nom. Orders v. Stotts, 459 U.S. 969 (1982); Culbreath, $630 \mathrm{~F} .2 \mathrm{~d}$ at $20-21$.

s 436 U.S. 1 (1978).

ss Id. at 13-15. 
'hearing." "ss The Court added that there was particularly strong reason to require informative notice when the notice was being directed to laypersons who were likely to be unsophisticated about their legal rights. ${ }^{37}$

Craft involved a quasi-administrative proceeding, in which the government was a party in interest, as opposed to a judicial proceeding. While that difference might affect the precise content of the notice which would be required in each context, nevertheless the underlying principle is the same. In Mullane, which involved a judicial proceeding between private parties, the Court observed that the purpose of notice is to enable the recipient to "choose for himself whether to appear or default, acquiesce or contest."”s That standard was not met in Craft because although the plaintiffs were alerted to the threat to their interests, they were not informed of the availability of a hearing. The notice provided to majority employees under the Thaggard courts' approach is similarly flawed since majority employees are not advised that they must choose between intervening in the original suit or being bound by its result.

Indeed, the notice which majority employees receive is even less adequate than that found deficient in Craft. In Craft, the plaintiffs at least received some tangible, affirmative indication that the state's coercive power was being invoked against them. Under the Thaggard courts' approach, the original parties are not required to provide the majority employees with any notice whatsoever; rather, the mere existence of the original suit may be deemed sufficient to put the majority employees on notice. ${ }^{59}$ For example, some motions to intervene have been denied as untimely even though the majority employees sought to intervene before a consent decree establishing quotas was proposed, on the ground that even without formal notice the possibility of such relief should have been apparent earlier from the nature of the suit.. ${ }^{60}$ The

ss Id. at 14 (footnote omitted).

s5 Id. at 15 n.15.

${ }^{38}$ Mullane, 339 U.S. at 314. For other cases which consider the limits that due process places on the content of notice in judicial proceedings, see In re Center Wholesale, Inc., 759 F.2d 1440, 1448-50 (9th Cir. 1985) (notice in a bankruptcy proceeding found to be constitutionally inadequate); Harris v. Bailey, 574 F. Supp. 966, 970-71 (W.D. Va. 1983) (notice provided in a post-judgment garnishment proceeding found to be constitutionally inadequate); Julen v. Larson, 25 Cal. App. 3d 325, 328, 101 Cal. Rptr. 796, 798 (1972) (notice given in foreign language found to be constitutionally inadequate).

39 See supra notes 52-53 and accompanying text; infra note 60 and accompanying text.

6o See Culbreath v. Dukakis, 630 F.2d 15, 17-21 (1st Cir. 1980) (original suit filed in 1974; organization representing majority employees moved to intervene in November, 1978, 
Thaggard approach places an excessive burden of inquiry on majority employees, ${ }^{61}$ with a concomitant risk that they will misapprehend the nature of the threat to their interests and thus fail to intervene promptly. ${ }^{62}$

There is potentially another constitutional defect in the notice procedure which underlies the Thaggard courts' mandatory intervention system. To call it a "procedure" is to suggest the existence of an element of regularity which is totally lacking: the original parties are not required to do anything to set the procedure in motion; the provision of notice is totally arbitrary; and courts are embroiled in case-by-case inquiries into what the majority employees should have known. Such a procedure is at best anomalous in light of modern Supreme Court cases in this area, which have focused on the likelihood that detailed notice procedures established by statute or rule will result in actual notice being given to all the intended recipients. ${ }^{63}$ Although the cases are ambiguous, they arguably suggest that due process requires something more than actual notice; specifically, due process may require the existence of a "formally and officially predetermined and declared [notice system] which, when followed according to its own terms, is reasonably calculated to provide actual notice."

one month before proposed consent decree was submitted to district court; intervention denied as untimely).

${ }^{61}$ Cf. Craft, 436 U.S. at 15 n.15 (due process requires especially informative notice given the lack of sophistication of the laypersons to whom notice was directed). In Mennonite Bd. of Missions v. Adams, 462 U.S. 791 (1983), the Court considered a mortgagee's challenge to a statute which provided that land could be sold at a tax sale after notice was posted at the county courthouse, published in a newspaper, and mailed to the last known address of the property owner. In holding that the notice procedure violated due process, the Court rejected the dissenting justices' argument that the procedure was sufficent because mortgagees were likely to be sophisticated parties who could apprise themselves of the pendency of tax sales. Id. at 799-800. But see id. at 807-09 (O'Connor, J., dissenting) (criticizing the majority opinion by arguing that "[w]hen a party is unreasonable in failing to protect its interest despite its ability to do so, due process does not require that the State save the party from its own lack of care").

${ }^{62}$ Cf. Logan v. Zimmerman Brush Co., 455 U.S. 422, 434 n.7, 437 (1982) (although the state can extinguish the claims of litigants who do not comply with procedural rules governing the presentation of those claims, such rules must be "reasonable").

${ }^{63}$ See, e.g., Mennonite Bd. of Missions, 462 U.S. at 797-800; Greene v. Lindsey, 456 U.S. 444, 449-56 (1982); Mullane, 339 U.S. at 314-15, 318-19.

ot Robert Casad, JuRisdiction in Crvil Actions II 2.03[1][c] (1983) (footnote omitted). Casad bases his argument for the existence of such a requirement on Wuchter v. Pizutti, 276 U.S. 13 (1928). In Wuchter, the Supreme Court found that a notice procedure established by statute violated due process because it did not have a reasonable likelihood of providing actual notice. $I d$. at 19-25. The court held that the due process rights of the defendant had been violated even though the defendant had in fact received actual notice of the action, although by a means which was not required by the statute: "[n]ot having been directed by 
courts' procedure is clearly deficient.

Another potential problem with the mandatory intervention system endorsed by the Thaggard courts centers not upon notice, but upon personal jurisdiction and venue. The Thaggard system binds majority employees if they fail to intervene in the forum chosen by the plaintiffs in the original action. Yet in some instances the original court may have lacked personal jurisdiction over the majority employees, or those employees may have had valid objections to venue. ${ }^{65}$ Binding those majority employees would therefore circumvent the statutes setting limits on personal jurisdiction and venue ${ }^{66}$ and may, in the case of personal jurisdic-

the statute [the notice] can not, therefore, supply constitutional validity to the statute or to service under it." Id. at 24 (citations omitted).

Other commentators have been more skeptical of the reach of Wuchter, see, e.g., RESTATEMENT (SECOND) OF Judgments $\$ 2$ comment d (1980), and the Supreme Court's subsequent references to the case do not seem to attribute a sweeping scope to it, see, e.g., National Equip. Rental, Ltd. v. Szukhent, 375 U.S. 311, 315 (1964). However, Casad's view derives at least implicit support from some recent Supreme Court cases. For example, in Mennonite Bd. of Missions, discussed supra at note 61, the Court announced the following sweeping principle: "Notice by mail or other means as certain to ensure actual notice is a minimum constitutional precondition to a proceeding which will adversely affect the liberty or property interests of any party, ... if its name and address are reasonably ascertainable." Id. at 800 (emphasis in original); see also id. at 800-03 (O'Connor, J., dissenting) ("Without knowing what state and individual interests will be at stake in future cases, the Court espouses a general principle ostensibly applicable whenever any legally protected property interest may be adversely affected.") (emphasis in original).

os Title VII contains no provisions governing personal jurisdiction; thus, the reach of courts' service of process in Title VII litigation is determined by the Federal Rules of Civil Procedure. See Fed. R. Crv. P. 1. Title VII does contain special venue provisions. See Title VII $\$ 706(f)(1), 42$ U.S.C. $\$ 2000$-5(f)(1) (1982). While situations in which majority employees will be outside the original court's jurisdiction or have valid venue objections are likely to be infrequent, nevertheless they could arise in cases involving multi-state employers, see, e.g., McAleer v. American Tel. \& Tel. Co., 416 F. Supp. 435, 436, 439 (D.D.C. 1976) (consent decree entered in federal district court in Philadelphia covers AT\&T employees nationwide; court faced with subsequent suit observed that "to require AT\&T employees from all over the country to litigate [reverse discrimination] claims in Philadelphia would as a practical matter nullify their Title VII rights"), or industry-wide consent decrees, compare United States v. Allegheny-Ludlum Indus., Inc., 517 F.2d 826, 834 (5th Cir. 1975) (consent decree entered in federal district court in Alabama covers more than 300,000 workers employed by nine steel companies at 240-250 plants), cert. denied, 425 U.S. 944 (1976), with Goins v. Bethlehem Steel Corp., 657 F.2d 62, 63-64 (4th Cir. 1981) (affirming dismissal of subsequent suit filed in federal district court in Maryland challenging Allegheny-Ludlum decree; only the federal district court in Alabama which entered the decree can exercise jurisdiction over challenges to it), cert. denied, 455 U.S. 940 (1982).

${ }^{68}$ Cf. Consumers Union, Inc. v. Consumer Prod. Safety Comm'n, 590 F.2d 1209, 1222 (D.C. Cir. 1978) (mandatory intervention would force potential intervenors to "accept the choice of a forum possibly sympathetic to the [original parties] and surely inconvenient or impossible for [the intervenors]"), rev'd on other grounds sub nom. GTE Sylvania, Inc. v. Consumers Union, Inc., 445 U.S. 375 (1980). But cf. Note, supra note 49, at 1572-74 \& n.130 (arguing that preclusion of nonintervenors to promote consolidation is acceptable "even if it 
tion, violate the due process clause. ${ }^{67}$

It is easy to envision a mandatory intervention system that would avoid the pitfalls of the Thaggard courts' approach: the original parties could be required to give majority employees formal notice of the opportunity to intervene, and intervention could be required only when consistent with limits on personal jurisdiction and venue. Yet there is strong reason to believe that federal courts lack the power to develop such a system sua sponte. Rule 83 of the Federal Rules of Civil Procedure authorizes district courts to improvise procedures only when they are "not inconsistent with these rules." sistent with the joinder provisions set out in rule 19, which states that a nonparty having an interest relating to the subject of an action shall be joined when "his absence may . . . leave any of the persons already parties subject to a substantial risk of incurring double, multiple, or otherwise inconsistent obligations."68 Rule 19 makes it the parties' responsibility "to make certain that the court has before it all those needed to enable it to serve the ends of justice." In In contrast, a mandatory intervention system would shift that responsibility to nonparties and disallow them any further opportunity to be heard if they failed to intervene in the original action. The resulting conflict between a court's improvisation and rule 19 would violate the limits that rule 83 sets on the discretionary power of the federal courts. ${ }^{\text {11 }}$

may sometimes achieve results inconsistent with rules of venue and service of process," except in cases where a special statutory provision for venue exists).

${ }_{67}$ See Bigelow v. Old Dominion Copper Mining \& Smelting Co., 225 U.S. 111, 137 (1912), overruled on other grounds, International Shoe Co. v. Washington, 326 U.S. 310 (1945); McCoid, supra note 48, at 713, 720. But see Restatement (Second) of Judgments $\S 41$ (2) \& comment $f$ (1980); Note, supra note 49 , at 1574-75.

${ }^{68}$ Each district court by action of a majority of the judges thereof may from time to time make and amend rules governing its practice not inconsistent with these rules. ... In all cases not provided for by rule, the district courts may regulate their practice in any manner not inconsistent with these rules.

Fed. R. Crv. P. 83; see also Republic Int'l Corp. v. Amco Eng'rs, Inc., 516 F.2d 161, 165-66 (9th Cir. 1975).

Fe F. R. Crv. P. 19(a). The authors of the rule made clear that its objectives are identical to those which would be served by a mandatory intervention system: avoiding duplicative litigation and the risk of inconsistent judgments. See FED. R. CIV. P. 19 advisory committee note, reprinted in 39 F.R.D. 69, 91 (1966). In addition, the rule directly addresses some of the issues which would need to be considered in developing a mandatory intervention system: it provides that the nonparty will not be joined if joinder would violate principles of personal jurisdiction, venue, or subject-matter jurisdiction. See FED. R. Crv. P. 19(a).

${ }^{70}$ Consumers Union, 590 F.2d at 1223.

${ }^{71} \mathrm{Cf}$. id. (rule 19 "puts the burden on existing parties and the court to bring in those whose presence is necessary or desirable [and a mandatory intervention principle] would 
In sum, principles of res judicata can preclude subsequent suits only if majority employees are given notice of the original action in a manner consistent with the requirements of due process. The Thaggard courts, however, dismiss subsequent suits in apparent reliance on a theory of mandatory intervention that fails to satisfy those requirements. Moreover, because of the constraints of rule 83 , federal courts lack the power to adopt procedures which could overcome that constitutional barrier.

\section{B. Comity}

In addition to relying on res judicata, the Thaggard courts base their decisions on a lack of subject-matter jurisdiction, dismissing subsequent suits in deference to the original court's power to control the operation of its consent decree. This approach suggests that the Thaggard courts are motivated by principles of comity. Those principles reflect the policy concerns that arise whenever two or more courts concurrently acquire jurisdiction ${ }^{72}$ over closely related cases. ${ }^{73}$ One concern is that the courts will unneces-

abrogate the rule and its purpose completely"); McGhee v. United States, 437 F.2d 995, 9991000 (Ct. Cl. 1971) (court rejects mandatory intervention; rather, the defendant "should have taken the initiative to consolidate" the original and subsequent suits).

72 In most cases that consider comity issues, none of the (multiple) actions has proceeded to judgment. See, e.g., Kerotest Mfg. Co. v. C-O-Two Fire Equip. Co., 342 U.S. 180, 181-82 (1952); Mann Mfg., Inc. v. Hortex, Inc., 439 F.2d 403, 405-06 (5th Cir. 1971). In contrast, in the cases considered in this comment, a judgment has been entered in the original action. Some courts have implied that once a judgment has been entered, principles of comity become inapplicable and the issue should be decided under principles of res judicata. See Penn General Casualty Co. v. Pennsylvania, 294 U.S. 189, 195 (1935); O'Hare Int'l Bank v. Lambert, 459 F.2d 328, 331 (10th Cir. 1972); Robertson v. Department of Defense, 402 F. Supp. 1342, 1345 (D.D.C. 1975). However, special considerations exist when - as often occurs in the employment discrimination context-the original court has issued an injunction which remains in effect and which could be modified by that court. See supra note 32. In such circumstances courts have concluded that principles of comity do continue to apply and can justify deferring to the court that issued the injunction. See Gregory-Portland Indep. School Dist. v. Texas Educ. Agency, 576 F.2d 81, 83 (5th Cir. 1978) (trial court should have dismissed or transferred the subsequent suit), cert. denied, 440 U.S. 946 (1979); Bergh v. Washington, 535 F.2d 505, 507 (9th Cir.) (affirming dismissal of subsequent suit), cert. denied, 429 U.S. 921 (1976); Exxon Corp. v. United States Dep't of Energy, 594 F. Supp. 84, 89-91 (D. Del. 1984) (transferring subsequent suit).

73 Some courts deem it appropriate to decline jurisdiction only when the two suits involve identical parties and issues. See, e.g., Great N. Ry. v. National R.R. Adjustment Bd., 422 F.2d 1187, 1193 (7th Cir. 1970); North Carolina v. Department of Health, Educ. \& Welfare, 480 F. Supp. 929, 932 (E.D.N.C. 1979); see also Consumers Union, Inc. v. Consumer Prod. Safety Comm'n, 590 F.2d 1209, 1219 \& nn.46-47 (D.C. Cir. 1978) (court found it inappropriate to decline jurisdiction when-as is the case with subsequent suits by majority employees-the plaintiff in the suit to be dismissed is not a party to the other action), rev'd on other grounds sub nom. GTE Sylvania, Inc. v. Consumers Union, Inc., 445 U.S. 375 (1980). 
sarily duplicate effort; another is that they may issue inconsistent judgments. ${ }^{74}$ The latter concern is closely related to the notion that courts should respect each other's authority and competence. ${ }^{75}$

Comity principles allow a court to respond to these concerns by exercising a discretionary authority to stay or dismiss a pending action, thereby deferring to another court. ${ }^{76}$ When all the courts involved are federal district courts, "no precise rule has evolved" to identify which court should proceed, ${ }^{77}$ although there is a presumption favoring the court that first acquired jurisdiction. ${ }^{78} \mathrm{How}-$ ever, this presumption can be overcome by various "equitable" considerations. ${ }^{79}$

But the power of federal courts to dismiss suits based on comity concerns is limited. The overwhelming majority of courts considering the issue have held it inappropriate to defer to another court when the plaintiff in the suit being dismissed cannot obtain a hearing in that other court. ${ }^{80}$ Further, there is reason to believe

Other courts are more flexible. See, e.g., Mann Mfg., 439 F.2d at 408 \& n.6 ("substantial overlap" is sufficient); Hilton Hotels Corp. v. Weaver, 325 F.2d 1010 (D.C. Cir. 1963) (dismissal affirmed even though defendants in the two cases were different), cert. denied, 376 U.S. 951 (1964); Exxon Corp., 594 F. Supp. at 90 (rejecting the approach taken in Consumers Union); see also Landis v. North Am. Co., 299 U.S. 248, 254-55 (1936) (appropriate to stay a suit pending resolution of a test case involving common issues but different parties).

The latter approach is clearly more responsive to policy concerns underlying the principles of comity, although it poses a greater risk of inequitable results. As long as this risk is taken into account, it would seem appropriate to adopt the more flexible approach in the employment discrimination context. 1975).

${ }^{74}$ See, e.g., Columbia Plaza Corp. v. Security Nat'l Bank, 525 F.2d 620, 626 (D.C. Cir.

76 See, e.g., Black's Law Dictionary 242 (5th ed. 1979) ("[C]ourts of one . . . jurisdiction will give effect to laws and judicial decisions of another . . . jurisdiction, not as a matter of obligation but out of deference and mutual respect.").

${ }^{78}$ See Will v. Calvert Fire Ins. Co., 437 U.S. 655, 662-63 (1978); Abbott Laboratories v. Gardner, 387 U.S. 136, 155 (1967); see also 5 C. WRIGHT \& A. MillER, supra note 31, § 1360, at 637-41; supra note 72 (citing cases dismissing subsequent suits). Another alternative is for one court to transfer the action before it to the district in which the other suit is pending. 28 U.S.C. § 1404 (1982); see, e.g., Exxon Corp., 594 F. Supp. at 91-92.

A court which believes that it is best suited to exercise jurisdiction can enjoin the parties from proceeding before other courts. See, e.g., Columbia Plaza Corp., 525 F.2d at 62729.

${ }^{77}$ Colorado River Water Conservation Dist. v. United States, 424 U.S. 800, 817 (1976).

${ }^{78}$ See, e.g., Consumers Union, 590 F.2d at 1218; O'Hare Int'l Bank v. Lambert, 459 F.2d 328, 331 (10th Cir. 1972).

79 Kerotest Mfg. Co. v. C-O-Two Fire Equip. Co., 342 U.S. 180, 183-84 (1952); see Columbia Plaza Corp., 525 F.2d at 627-29; cf. Semmes Motors, Inc. v. Ford Motor Co., 429 F.2d 1197, 1203-04 (2d Cir. 1970) (court considered equitable factors and concluded that second suit should have been stayed).

so See, e.g., Church of Scientology v. United States Dep't of the Army, 611 F.2d 738, $750 \mathrm{n.7}$ (9th Cir. 1979) (appropriate to decline jurisdiction "where the plaintiff is afforded a full and fair opportunity to be heard in the other forum"); Consumers Union, 590 F.2d at 
that this limitation would be endorsed by the Supreme Court.

In Colorado River Water Conservation District v. United States, ${ }^{81}$ the Court considered the relationship between a statutory grant of federal jurisdiction and the power of a federal court to defer to state court proceedings. The cornerstone of the Court's analysis was its recognition of the "virtually unflagging obligation of the federal courts to exercise the jurisdiction given them." 82 The Court noted that the broad leeway of lower federal courts to defer to other federal courts accorded with that principle, but only because in such situations the case would be considered somewhere in the federal system. ${ }^{83}$ As between federal and state courts, however, the "unflagging obligation" dictated a quite different approach to jurisdictional overlaps. The Court held that unless established abstention doctrines apply, federal courts should defer to state courts only in "exceptional" circumstances in which the "clearest of justifications" are present. ${ }^{84}$

Thus a strong presumption exists that federal courts should exercise their jurisdiction, even when the only result of their failure to do so would be to consign the parties to state court. Given that backdrop, it is difficult to justify dismissal when the outcome is that plaintiffs will never receive a hearing on the merits of their claims. ${ }^{85}$ While a court facing a subsequent suit in the employment discrimination context might have power under comity principles to refuse to exercise its jurisdiction until the majority employees attempt to intervene in the other federal court action, the court would exceed its power if it continued to demur after the majority employees tried unsuccessfully to intervene in the other suit.

Finally, even if the discretionary dismissal power is as expansive as the Thaggard courts suggest, its reach will ultimately be limited by the due process clause. Whether a subsequent court

1219 (power to decline jurisdiction "surely does not contemplate that fundamental rights of citizens will be adjudicated in forums from which they are absent"); Mann Mfg., 439 F.2d at 408 (subsequent court should defer to original court "so long as it is apparent that a remedy is available there"); see also Landis v. North Am. Co., 299 U.S. 248, 257 (1936) (a stay pending resolution of test case "is immoderate and hence unlawful unless so framed in its inception that its force will be spent within reasonable limits"). But cf. Special School Dist. v. Mallory, 506 F. Supp. 183, 185 (E.D. Mo. 1980) (after noting that subsequent suit was moot because plaintiff had been allowed to intervene in the original action, court added that "this Court would abstain from exercising its jurisdiction even assuming, arguendo, that the issues presented were not moot as a result of the plaintiff's joinder in the [original] action").

824 U.S. 800 (1976).

s2 Id. at 817 .

sa Id.

st Id. at 818-19.

ss See, e.g., Consumers Union, 590 F.2d at 1219 \& n.49, 1221 \& n.61. 
purports to defer to the original court on comity grounds or on the basis of res judicata, the net result of the dismissal should be measured against the same due process standards. And when the net result is that majority employees are left without a forum even though they never received formal notice of an opportunity to assert their interests, the requirements of due process have not been met. $^{86}$

\section{Title VII's Policy of Encouraging Settlements}

In addition to res judicata and principles of comity, the Thaggard courts have justified their dismissal of subsequent suits by invoking a Title VII policy favoring the voluntary resolution of employment discrimination disputes. The Thaggard courts argue that this policy would be frustrated if majority employees are allowed to bring subsequent suits which challenge consent decrees. While those courts are curiously inarticulate about exactly why that would be the case, the notion seems to be that potential exposure to such suits might discourage employers from entering into consent decrees. ${ }^{87}$

This pro-settlement policy is reflected in Title VII's procedural requirements and in the role it establishes for the EEOC. ${ }^{88}$ Before a would-be plaintiff may bring suit under Title VII, he must file a timely "charge" with the EEOC briefly describing his claim against his employer. ${ }^{89}$ After filing the charge, the plaintiff

${ }^{86}$ See supra notes 37-64 and accompanying text.

${ }^{87}$ See Thaggard, 687 F.2d at 69; Dennison, 658 F.2d at 696; Prate, 430 F. Supp. at 1375. Of these cases, only Dennison offers any explanation. See 658 F.2d at 696. One possible reason for the Thaggard courts' reticence is that the current incentives for settlement may be excessively strong. An employer defending against a class action suit may have significant monetary exposure from the plaintiffs' claims for back pay. For such an employer, a settlement which provides the plaintiffs with quotas but no back pay is quite attractive. It could be attractive to the plaintiffs as well, when compared to the prospect of litigation stretching out over several years and an uncertain chance of victory. However, the attractiveness of such a settlement from the employer's point of view is diminished significantly if the employer can subsequently be subjected to monetary liability by majority employees.

${ }_{88}$ See, e.g., Alexander v. Gardner-Denver Co., 415 U.S. 36, 44 (1974) ("Congress enacted Title VII . . . to assure equality of employment opportunities . . . . Cooperation and voluntary compliance were selected as the preferred means for achieving this goal. To this end, Congress created the Equal Employment Opportunity Commission and established a procedure whereby existing state and local equal employment opportunity agencies, as well as the Commission, would have an opportunity to settle disputes through conference, conciliation, and persuasion before the aggrieved party was permitted to file a lawsuit."); Weise v. Syracuse Univ., 522 F.2d 397, 411-12 (2d Cir. 1975); Oatis v. Crown Zellerbach Corp., 398 F.2d 496, 497-98 (5th Cir. 1968).

${ }_{89}$ Title VII $\S 706(e), 42$ U.S.C. § $2000 \mathrm{e}-5(\mathrm{e})$ (1982) ("A charge under this section shall be filed within one hundred and eighty days after the alleged unlawful employment practice 
must wait 180 days while the EEOC investigates and, if it finds the charge to be meritorious, attempts to resolve the dispute by "informal methods of conference, conciliation, and persuasion." "Only after 180 days have expired may the plaintiff sue on his own behalf.91 While the legislative history of Title VII confirms that Congress intended these procedural requirements to foster settlement, ${ }^{82}$ it is noteworthy that the requirements pertain only to the period before a suit is filed.

Congress also enacted several special provisions governing the conduct of Title VII suits once litigation is commenced. For instance, Congress provided for the expedited consideration of Title VII suits, ${ }^{93}$ the appointment of attorneys for private plaintiffs and the waiver of fees, costs, and security, ${ }^{94}$ awards of attorneys' fees, ${ }^{95}$ special venue rules, ${ }^{96}$ and stays of Title VII suits for up to sixty days pending resolution of state or local proceedings or of additional efforts to conciliate. ${ }^{97}$ However, of these provisions, only the last is clearly aimed at promoting settlements. The others simply make it easier for plaintiffs to bring employment discrimination suits. ${ }^{98}$ Moreover, aside from the specific provisions discussed here, the legislative history suggests that Congress intended Title VII suits to be governed by the same procedures as other types of litigation. ${ }^{98}$

Thus, in encouraging the voluntary resolution of employment discrimination disputes, Congress focused primarily on the period

occurred."). The period is extended to up to 300 days if the charging party also institutes proceedings at the state or local level. $I d$.

90 Id. § 706(b), 42 U.S.C. § $2000 \mathrm{e}-5$ (b) (1982).

21 However, the plaintiff can act earlier if the EEOC dismisses the charge as meritless. Id. § 706(f)(1), 42 U.S.C. § 2000e-5(f)(1) (1982); see Weise v. Syracuse Univ., 522 F.2d 397, 411-12 (2d Cir. 1975).

${ }^{92}$ See Johnson v. Seaboard Air Line R.R. Co., 405 F.2d 645, 651 \& nn.12-15 (4th Cir. 1968) (discussing legislative history of Title VII), cert. denied, 394 U.S. 918 (1969); 405 F.2d at 655 \& nn.24-26 (Boreman, J., dissenting) (same).

93 Title VII \& 706(f)(5), 42 U.S.C. § $2000 \mathrm{e}-5(\mathrm{f})(5)(1982)$.

๑ Id. § 706(f)(1), 42 U.S.C. $\S 2000 \mathrm{e}-5(\mathrm{f})(1)(1982)$.

${ }^{23}$ Id. § 706(k), 42 U.S.C. $\$ 2000 \mathrm{e}-5(\mathrm{k})(1982)$.

98 Id. $\$ 706(\mathrm{f})(3), 42$ U.S.C. $\S 2000 \mathrm{e}-5(\mathrm{f})(3)(1982)$.

97 Id. § 706(f)(1), 42 U.S.C. § $2000 \mathrm{e}-5(\mathrm{f})(1)(1982)$.

os That goal was discussed by Senator Humphrey in his detailed explanation of the "Dirksen-Mansfield" substitute amendment. See 110 Cong. REc. 12,721-25 (1964), reprinted in Equal Employment Opportunity Commission, Legislative History of Tttles VII and IX of THE Civir Rights ACT of 1964, at 3003-08 (1968) [hereinafter cited as 1964 LegisLATIVE HistoRy].

20 See 111 CoNG. REc. 7213 (1964) (interpretive memorandum introduced by Sens. Clark and Case) (once suit is brought, it "would proceed in the usual manner for litigation in the Federal courts"), reprinted in 1964 Legislative History, supra note 98, at 3044. 
leading up to the filing of suit. To the extent that Congress considered the pro-settlement policy to be relevant thereafter, it implemented the policy by providing for brief stays pending conciliation. While it is easy to imagine additional post-filing measures that Congress might have adopted to further this policy, courts should hesitate to take steps which Congress itself failed to take. ${ }^{100}$ In short, since Congress has not explicitly authorized the courts to dismiss subsequent suits in order to promote settlements, the courts should be reluctant to imply such a power.

Even assuming that the pro-settlement policy has some relevance in determining whether subsequent suits by majority employees should be allowed, it is not the only relevant policy. By permitting majority as well as minority employees to bring suits under Title VII, ${ }^{101}$ Congress has expressed a competing policy-the desire to protect the interests of majority employees. While the scope of this protection is still unclear, courts have acknowledged that the use of quotas is limited by the substantive rights of majority employees. ${ }^{102} /$ These rights are meaningless, however, if majority employees lack an opportunity to assert them/Courts should therefore be wary of procedural shortcuts, like the dismissal of subsequent suits, that encourage settlement of original actions but simultaneously restrict majority employees' ability to protect their interests.

간 This view of Title VII's pro-settlement policy is supported by the Supreme Court's decision in W.R. Grace \& Co. v. Local Union 759. ${ }^{103}$ There the employer had entered into a conciliation agreement with the EEOC that required the employer to maintain the existing percentage of female employees in its workforce in the event of layoffs. However, a collective bargaining agreement called for layoffs to be made on the basis of seniority. When the employer chose to follow the conciliation agreement and laid off male em-

100 See, e.g., Mercado v. Calumet Fed. Sav. \& Loan Ass'n, 763 F.2d 269, 271 (7th Cir. 1985) ("Congress always has some objective in view when it legislates, and it is always possible to move a little farther in the direction of that objective. The fact that Congress has pointed in a particular direction does not authorize a court to march in that direction without limit.").

${ }^{101}$ See McDonald v. Santa Fe Trail Transp. Co., 427 U.S. 273, 280 (1976). In McDonald, the Court also held that white employees could bring employment discrimination claims under 42 U.S.C. § 1981 (1982). 427 U.S. at 286-87.

${ }^{102}$ See United Steelworkers of Am. v. Weber, 443 U.S. 193, 208-09 (1979) (implicitly identifying limits on an employer's ability to adopt quotas without any action by a court). Majority employees may have even broader rights with respect to quotas established by a consent decree, or imposed by a court after a trial. See infra note 133.

${ }^{103} 461$ U.S. 757 (1983). 
ployees in violation of the collective bargaining agreement, the union submitted the dispute to arbitration. On appeal, the Court upheld arbitration awards in favor of laid-off male employees. ${ }^{104}$

In the course of its decision, the Court made clear that Title VII's pro-settlement policy was not without limits: the Court refused to permit "the employer's added incentive to conciliate [to] be paid for with the union's contractual rights."105 Also, the Court recognized that the pro-settlement policy had to be balanced with competing federal interests, here the federal labor policy of promoting certainty in collective bargaining relationships. It concluded that "[a]bsent a judicial determination," neither the EEOC nor the employer could abrogate the collective bargaining agreement without the union's consent. ${ }^{108}$

W.R. Grace thus confirms that there are substantial limits on the extent to which Title VII's pro-settlement policy insulates voluntary arrangements such as conciliation agreements from later challenges by nonparty majority employees. One might argue, however, that these limits do not apply to the Thaggard cases because they differ from W.R. Grace in two significant respects: (1) the male employees' claims in W.R. Grace were contract-based, while the claims of applicants or nonunion majority employees who bring subsequent suits are typically statute-based; and (2) the dispute in W.R. Grace involved an out-of-court agreement between the EEOC and the employer, while the subsequent suits in the Thaggard cases involve court-approved consent decrees.

Nevertheless, these differences are insufficient to distinguish the two situations. First, it is not clear why applicants or nonunion employees in subsequent suits should have less opportunity to assert their Title VII claims than unionized employees have to raise

\footnotetext{
104 Id. at $763-64,772$.
}

$10 \mathrm{Id}$. at 771.

${ }_{106} I d$. at 771-72. The Court did not define what it meant by suggesting that a collective bargaining agreement could be abrogated after "a judicial determination." When a court enters a consent decree it does not resolve the underlying issue of whether the employer actually discriminated against minority employees in violation of Title VII or other law. See supra notes 1, 25 and accompanying text. Thus if a "judicial determination" means a trial on the merits of that issue, then the level of review undertaken by a court which enters a consent decree would appear to be insufficient to justify abrogating a collective bargaining agreement absent the union's consent.

However, elsewhere in its opinion the Court appeared to reserve that question. See 461 U.S. at 767 n.9 (citing Dennison, see supre notes 14-17 and accompanying text, Court noted that it was not deciding whether an arbitral award "could be enforced in the face of a valid judicial alteration of seniority provisions”); Grann v. City of Madison, 738 F.2d 786, 795 n.6 (7th Cir.) (interpreting footnote 9 of W.R. Grace), cert. denied, 105 S. Ct. 296 (1984). 
their contractual claims. ${ }^{107}$ Second, although judicial oversight of consent decrees provides a potential check against abuse that does not exist for out-of-court agreements, the effectiveness of that check is ultimately limited. Courts do not resolve the merits of the underlying dispute when they review consent decrees, ${ }^{108}$ and the original parties are unlikely to assert the majority employees' arguments very vigorously when those arguments could cause the court to withhold approval of the consent decree.

In sum, Title VII's pro-settlement policy seems far less expansive and free-floating than the Thaggard courts suggest. And even if the Thaggard courts are correct in that respect, the policy must nevertheless be balanced against the competing federal interest in the adequate protection of the rights of majority employees. Thus, it seems doubtful that the pro-settlement policy provides any real support for the Thaggard courts' adoption of a mandatory intervention system.

In addition, even if there was no doubt that Congress approved of the Thaggard courts' system, the inquiry would not be at an end. The right to bring a cause of action under Title VII is a form of property that is protected by the due process clause, and that therefore cannot be extinguished in a way that violates the clause. ${ }^{109}$ The Thaggard courts' mandatory intervention system-under which this property interest can be extinguished without any notice to majority employees-violates established principles of due process. ${ }^{110}$ The due process objection would exist even if Congress had explicitly incorporated the Thaggard system into Title VII: the Supreme Court has consistently rejected the argument that because the legislature is not obligated to grant a property interest to someone, it can choose to grant the interest on the condition that it can be withdrawn without regard to due process. ${ }^{111}$ Thus, even if Title VII's pro-settlement policy is as expansive as the Thaggard courts suggest and even if it outweighs the competing interest in protecting majority employees' rights, the mandatory intervention system adopted by those courts is invalid under the due process clause.

${ }^{107}$ But see infra note 137.

${ }^{108}$ See supra notes 1, 25.

${ }^{108}$ See Logan v. Zimmerman Brush Co., 455 U.S. 422, 428-31 (1982) ("Mullane . . held that a cause of action is a species of property protected by the Fourteenth Amendment's Due Process Clause.").

110 See supra notes 33-67 and accompanying text.

11 See Logan, 455 U.S. at 431-33; Vitek v. Jones, 445 U.S. 480, 490-91 \& n.6 (1980). 


\section{Reducing the Costs Imposed by Collateral Attacks}

The preceding section demonstrated that requiring intervention without providing adequate notice to potential intervenors violates the due process clause, and that courts lack the power to cure that constitutional defect. It also showed that principles of comity offer no support for courts to decline jurisdiction in favor of unavailable forums. Finally, it established that the pro-settlement policy of Title VII does not justify dismissal of subsequent suits by majority employees.

What this means is that both existing and future consent decrees that establish quotas are open to collateral attack by nonparty majority employees. As the Thaggard courts noted, such subsequent suits pose several dangers: unfairness to the original parties, the risk of inconsistent judgments, and duplication of effort. ${ }^{112}$ However, there are several means of reducing or eliminating these problems which should be explored by the courts.

Intervention. Courts should relax the timeliness requirement of rule 24 and allow nonparty majority employees or their union to intervene in the original action at any stage, rather than force untimely intervenors to bring their claims in a separate suit. ${ }^{113}$ This approach would eliminate the possibility of inconsistent judgments, since a court could modify its judgment in the original action to accord with any relief granted to majority employees. ${ }^{114}$ Whenever possible, the intervenors should be designated as representatives of a class of majority employees, so that later efforts to intervene or to bring subsequent suits can be barred under traditional principles of res judicata. ${ }^{115}$

112 See supra notes 6-20 and accompanying text.

113 Such a liberalization should be within the substantial discretion which courts enjoy in making timeliness determinations. Certainly the need to avoid violating majority employees' due process rights on the one hand, and the risk of inconsistent judgments on the other, would appear to be an "unusual circumstance" capable of justifying late intervention. See supra note 53.

A liberal approach to intervention was taken in EEOC v. American Tel. \& Tel. Co., 506 F.2d 735 (3d Cir. 1974). There the trial court entered a consent decree on January 18, 1973. A union representing majority employees had been "repeatedly invited to join in the negotiations" leading to the decree, but had remained aloof. Id. at 741. The union finally sought intervention on February 9, 1973, and the Third Circuit allowed it "to intervene under Rule $24(a)(2)$ as a party defendant." Id.

${ }_{114}$ See supra note 32 (discussing the original court's power to modify the decree).

115 See supra note 43 (discussing res judicata in class action context); Miller v. Staats, 706 F.2d 336, 339 \& n.22 (D.C. Cir. 1983) (allowing a class of majority employees to intervene in original suit); see also Otero v. New York City Hous. Auth., 354 F. Supp. 941, 945 n.7 (S.D.N.Y.) (allowing a group of potential residents to intervene and be certified as a defendant class under rules $23(\mathrm{a})$ and $23(\mathrm{~b})(1)(\mathrm{B})$ in a lawsuit over the allocation of units in 
Joinder. Another way in which courts and the original parties can reduce or eliminate the threat of subsequent suits is by joining the majority employees or their union as parties to the original action. Several provisions of the Federal Rules of Civil Procedure are relevant to joinder. Rule 20(a) provides that

[a]ll persons . . . may be joined in one action as defendants if there is asserted against them jointly, severally, or in the alternative, any right to relief in respect of or arising out of the same transaction, occurrence, or series of transactions or occurrences and if any question of law or fact common to all defendants will arise in the action. ${ }^{116}$

While the joinder of majority employees or their union seems to meet the "common question of law or fact" requirement, the "right to relief" requirement would not appear to be satisfied since the minority plaintiffs seek no relief from them. However, some courts have interpreted the latter requirement as permitting joinder when the nonparty has interests which would be affected by the lawsuit. ${ }^{17}$ This seems to be the better view, and joinder of majority employees or their union should be allowed under rule 20(a).

The second provision is rule 19(a)(2), which provides that a person shall be joined when

he claims an interest relating to the subject of the action and is so situated that the disposition of the action in his absence may . . . leave any of the persons already parties subject to a substantial risk of incurring double, multiple, or otherwise inconsistent obligations by reason of his claimed interest. ${ }^{118}$

Majority employees or their union would seem to meet both requirements of this test. Indeed, a number of courts have ordered the joinder of unions under rule 19(a) when the relief sought in the original action would conflict with their collective bargaining

a public housing project), rev'd on other grounds, 484 F.2d 1122 (2d Cir. 1973).

${ }^{116}$ FED. R. Civ. P. 20(a). In addition, the nonparty can be joined only if he is subject to the process of the court and cannot raise valid objections to venue. See FED. R. Crv. P. 20 advisory committee note ("The provisions of this rule for the joinder of parties are subject to rule 82 (Jurisdiction and Venue Unaffected).").

117 See, e.g., Held v. Missouri Pac. R.R., 373 F. Supp. 996, 1000 (S.D. Tex. 1974) (joinder of union under rule 20 (a) is appropriate "[i]n light of the critical involvement of the collective bargaining agreement and its interpretation and application to plaintiff's allegations").

118 FED. R. Crv. P. 19(a). Rule 19(a) further provides that a person shall not be joined if doing so would violate principles of personal jurisdiction, subject-matter jurisdiction, or venue. Rule 19(b) identifies several factors which courts should consider in determining whether to allow the action to proceed if the person cannot be joined. 
agreement. ${ }^{119}$ Courts have been more reluctant to order the joinder of individual majority employees, although joinder has been ordered in several cases. ${ }^{120}$

Yet there are some practical problems with joinder in this context. First, it is unclear whether a union can or should represent the interests of majority employees or applicants in a contest against minority employees or applicants: not only is the union likely to have members on both sides of the dispute, ${ }^{121}$ but it also

119 See EEOC v. MacMillan Bloedel Containers, Inc., 503 F.2d 1086, 1095-96 (6th Cir. 1974); McDowell v. Safeway Stores, Inc., 33 Fair Empl. Prac. Cas. (BNA) 1734, 1735 (E.D. Ark. 1981); Coker v. Marmon Group, Inc., 455 F. Supp. 398, 401 (D.S.C. 1978); see also Annot., 22 A.L.R. Fed. 765, 823-28 (1975); 7 C. Wright \& A. Miller, Federal Practice ANd Procedure \& 1620 (1972 \& Supp. 1985); cf. International Bhd. of Teamsters v. United States, 431 U.S. 324, $356 \&$ n.43 (1977) (even though union found not to have violated Title VII, it "will properly remain in this litigation as a defendant so that full relief may be awarded the victims of the employer's post-Act discrimination"). But see Potter v. Continental Trailways, Inc., 480 F. Supp. 207, 212-13 (D. Colo. 1979) ("Since union members have no vested rights in seniority positions based on illegal exclusions, the unions simply cannot claim an interest in protecting so-called seniority rights of its members.").

However, there is considerable resistance to finding that the union is an indispensable party whose absence requires dismissal under rule 19(b). See B. Schlei \& P. Grossman, Employment Discrimination Law 1107 \& n.74, 1108-09 \& n.87 (1983); see also Hibbler v. Miller's of Birmingham Bankhead Highway, Inc., 496 F.2d 1171, 1172 (5th Cir. 1974) (per curiam). But see McDowell, 33 Fair Empl. Prac. Cas. (BNA) at 1735 (union held to be an indispensable party; joinder impossible because union not named in EEOC charge).

Among courts ordering the joinder of unions, some expressly limit the union's participation to the remedy stage, see, e.g., Coker, 455 F. Supp. at 402, while others appear to give the union the option of also participating in the determination of liability, see, e.g., MacMillan Bloedel Containers, Inc., 503 F.2d at 1095.

${ }^{220}$ Those approving joinder include English v. Seaboard Coast Line R.R., 465 F.2d 43, 46-48 (5th Cir. 1972), and Bremer v. St. Louis S.R.R., 310 F. Supp. 1333, 1339-40 (E.D. Mo. 1969) (individual majority employee who holds position allegedly denied to minority plaintiff in violation of Title VII held to be a necessary party). Those rejecting it include Spirt v. Teachers Ins. \& Annuity Ass'n, 416 F. Supp. 1019, 1023 (S.D.N.Y. 1976) (since majority employees "cannot legitimately assert a protectable interest, they need not be joined"), and Jackson v. Sargent, 394 F. Supp. 162, 173 (D. Mass.) (motion to dismiss for failure to join a necessary party denied), aff'd sub nom. Jackson v. Dukakis, 526 F.2d 64 (1st Cir. 1975). Courts are very unwilling to find majority employees to be indispensable parties in whose absence the action must be dismissed under rule 19(b). See, e.g., English, 465 F.2d at 48 \& n.13.

${ }^{121}$ See Commonwealth v. O'Neill, 100 F.R.D. 354, 356 (E.D. Pa. 1983) (describing union's ambiguous role in a Title VII suit), aff'd mem., 746 F.2d 1465 (3d Cir. 1984); Banks v. Seaboard Coast Line R.R., 51 F.R.D. 304, 305 (N.D. Ga. 1970) (union has "equal duty" to represent interests of majority and minority members; hence, it "cannot fairly and adequately" represent the former in the lawsuit brought by the latter); 18 WRIGHT, MnLER \& Cooper, supra note 31, § 4456, at 492-93; see also English, 465 F.2d at $46-47$ (although a union can adequately represent the interests of its majority members in some cases, in other cases individual majority members should be joined). But see EEOC v. American Tel. \& Tel. Co., 556 F.2d 167, 173 (3d Cir. 1977) (union representatives challenging a consent decree "recognize that in making their broad-gauged challenge they may be acting inconsistently with the best interests of some of the persons whom they represent in the collective 
may be difficult for the union to represent the interests of majority applicants who are not yet union members. ${ }^{122}$ Second, if no union exists or if the union is not an adequate representative, then individual majority employees or applicants will have to be joined. With all but the smallest employers, it would probably be necessary to certify a defendant class of applicants or employees, ${ }^{123}$ and it would be up to the plaintiff to designate the class representative. ${ }^{124}$ But it may be difficult to identify a willing class representative, ${ }^{125}$ especially given the uncertainty about whether that representative would be reimbursed for attorneys' fees. ${ }^{126}$

bargaining process, but point out that this potential conflict is inherent in the collective bargaining relationship"), cert. denied, 438 U.S. 915 (1978); Bowe v. Colgate-Palmolive Co., 416 F.2d 711, 719 (7th Cir. 1969); B. Schlei \& P. Grossman, supra note 119, at 1108 n.83; see also Sagers v. Yellow Freight Sys., Inc., 58 F.R.D. 54, 61-62 (N.D. Ga. 1972) (individual majority employees are not indispensable parties because the union will adequately represent their interests; however, they should be notified of the pendency of the action), vacated on other grounds, 68 F.R.D. 686, 690 (N.D. Ga. 1975).

${ }^{122}$ But see Schwarzschild, supra note 25, at 925-26 (although applicants were neither members of the majority employees' union nor represented by it in collective bargaining, the union might be able to represent their interests in litigation).

${ }^{123}$ No cases have been found in which majority employees or applicants were joined as a defendant class. This may be due to the availability of the seemingly less cumbersome option of having unions represent the interests of majority employees and applicants. Nevertheless, it appears that majority employees or applicants could qualify as a defendant class under rules $23(\mathrm{~b})(1)(B)$ or 23(b)(2) of the Federal Rules of Civil Procedure. See Note, Defendant Class Actions, 91 Harv. L. Rev. 630, 633-34 (1978); 1 Herbert Newberg, NewBERG on Class Actions $\$ \S 4.45,4.54-.57,4.63-.64$ (1985); see also supra note 115 (defendant class of intervenors certified in Otero).

124 See Note, supra note 123 , at 639-40.

${ }^{125}$ However, it should be noted that a court may decline to certify a defendant class if it is not satisfied that the designated class representative will adequately represent the class. See FED. R. Crv. P. 23(a)(4); see also Note, supra note 123, at 641. See generally id. at 64147 (discussing methods of ensuring that representation is adequate); $1 \mathrm{H}$. NEwBERG, supra note $123, \S 4.58$ (same).

${ }^{128}$ Section $706(\mathrm{k})$ of Title VII provides: "In any action or proceeding under this title the court, in its discretion, may allow the prevailing party . . . a reasonable attorney's fee as part of the costs . . ." 42 U.S.C. $\$ 2000 \mathrm{e}-5(\mathrm{k})$ (1982). Similarly, section 1988 of the Civil Rights Attorney's Fees Awards Act of 1976 provides: "In any action or proceeding to enforce a provision of [42 U.S.C.] sections 1981, 1982, 1983, 1985, and 1986 of this title, . . the court, in its discretion, may allow the prevailing party . . . a reasonable attorney's fee as part of costs." 42 U.S.C. § 1988 (1982).

Courts and commentators have interpreted these statutes as being intended to favor plaintiffs. For example, prevailing plaintiffs are denied fees only in rare instances. See, e.g., Newman v. Piggie Park Enters., Inc., 390 U.S. 400, 402 (1968); Tamanaha, The Cost of Preserving Rights: Attorneys' Fee Awards and Intervenors in Civil Rights Litigation, 19 HaRv. C.R.-C.L. L. REv. 109, 125 \& nn.68, 69 (1984). In contrast, prevailing defendants are awarded fees only "upon a finding that the plaintiff's action was frivolous, unreasonable, or without foundation, even though not brought in subjective bad faith." Christiansburg Garment Co. v. EEOC, 434 U.S. 412,421 (1978).

This structure evolved in the two-party context of minority employees suing their employer, and it is difficult to determine how majority employees should fit into it. The issue 
Even if these potential problems can be resolved and joinder proves workable in this context, the original parties may prefer to risk subsequent suits rather than stir up opposition which otherwise might remain dormant. In that event, a court should acquiesce in the parties' decision and not compel the joinder of other parties.

Prospective Remedies Only. If a consent decree has been entered and quotas have begun to operate before majority employees enter the dispute-whether by intervention, by joinder, or by bringing a subsequent suit-the employer should not be penalized for having complied with the decree. Courts should not award damages to majority employees, and should refuse to rescind hirings and promotions already made under the decree: in the event that majority employees triumph, contested quotas would be modi-

has been considered to some extent in cases where minority plaintiffs have asked courts to award attorneys' fees against unions or majority employees who intervened as defendants. Most courts have considered the intervenors to be "defendants" for the purposes of attorneys' fee statutes, and have required them to pay a portion of the prevailing plaintiffs' fees. See, e.g., Vulcan Soc'y v. Fire Dep't, 533 F. Supp. 1054, 1061-63 (S.D.N.Y. 1982); Tamanaha, supra, at 149 n.143. Others have considered them to be "functionally plaintiffs" and have refused to require them to pay the plaintiffs' fees. See, e.g., Kirkland v. New York State Dep't of Correctional Servs., 524 F. Supp. 1214, 1217-19 (S.D.N.Y. 1981).

The latter view seems more in keeping with the legislative history of the attorneys' fees statutes, which suggests that a party's formal designation as defendant or plaintiff should not be determinative. See S. REP. No. 1011, 94th Cong., 2d Sess. 4 n.4 (1976); Kirkland, 524 F. Supp. at 1218. Furthermore, the legislative history does not suggest that courts should draw distinctions based on whether the person seeking fees belongs to a minority group or a majority group. S. REP. No. 1011, supra, at 2-5. But see Tamanaha, supra, at 148-52 ("Courts must strongly favor a party found to be in a minority group [in part because] civil rights statutes themselves were written mainly for minority groups, and for many years have been used exclusively by them . . . ."). Under this view, majority employees would not be required to pay minority employees' attorneys' fees unless the majority employees' claims satisfied the Christiansburg Garment standard of "frivolous, unreasonable, or without foundation." Furthermore, majority employees should be able to recover their own attorneys' fees from their employer if they can satisfy the more lenient standards for prevailing plaintiffs. See, e.g., Miller v. Staats, 706 F.2d 336, 340-42 (D.C. Cir. 1983).

An alternate, non-statutory ground exists under which a majority employee who either serves as a class representative, or litigates on his own behalf and thereby confers benefits on other majority employees, might be able to recover attorneys' fees from the employer or the other employees. It is the so-called "common benefit" or "common fund" theory, whereby a litigant conferring a benefit on a group of people can recover attorneys' fees from that group or from the opposing party. See, e.g., Hall v. Cole, 412 U.S. 1, 5-9 (1973); 6 J. Moore, W. Taggart \& J. Wicker, Moore's Federal Practice I 54.77[2] (2d ed. 1981 \& Supp. 1985). One court has applied this theory in the employment discrimination context to grant attorneys' fees to members of a plaintiff class whose motion to intervene to challenge a proposed settlement was denied, but whose participation in modifying the settlement agreement was nevertheless deemed beneficial to the class as a whole. See Alaniz v. California Processors, Inc., 13 Fair Empl. Prac. Cas. (BNA) 738, 740-42 (N.D. Cal. 1976). 
fied or eliminated prospectively. ${ }^{127}$ In addition, courts could decline to interfere with the operation of quotas pending the resolution of the majority employees' claims, except in extreme situations. ${ }^{128}$

Limiting the Issues. Finally, whether majority employees enter the dispute by way of intervention, or joinder, or by bringing a subsequent suit, the role which they play can be strictly tailored to reflect the nature of their substantive interests. Although the Supreme Court has not yet determined the extent of those interests in a case involving a consent decree, ${ }^{128}$ the best guidance to that question can be found in United Steelworkers of America $v$. Weber. ${ }^{130}$

In Weber, the Supreme Court considered a majority employee's Title VII challenge to an affirmative-action plan that had been adopted by the employer without any involvement by a court, rather than established by a consent decree. The Court observed with approval that the plan was "designed to break down old patterns of racial segregation and hierarchy" manifested in a sharp difference between the percentages of blacks in the training program at issue and in the local workforce. ${ }^{131}$ The Court also noted that the plan did not "unnecessarily trammel" white employees' interests since "[it] does not require the discharge of white workers and their replacement with new black hirees [nor] does the plan create an absolute bar to the advancement of white employees [since] half of those trained in the program will be white. [Finally, it] is a temporary measure."132

${ }^{12 z}$ Courts could reach this result by holding that good faith compliance with the terms of a consent decree does not violate Title VII or other law. See Ashley v. City of Jackson, 464 U.S. 900, 903 (1983) (Rehnquist, J., dissenting from denial of certiorari); cf. Title VII § 713(b), 42 U.S.C. § 2000e-12(b)(1) (1982) (establishing a defense for employers who take actions "in good faith, in conformity with, and in reliance on any written interpretation or opinion of the [EEOC]"). Alternatively, courts could use their discretionary remedial authority under Title VII to deny majority employees relief for the period prior to adjudication of their claims. See id. § 706(g), 42 U.S.C. $\S 2000 \mathrm{e}-5(\mathrm{~g})$ (1982); Franks v. Bowman Transp. Co., 424 U.S. 747, 764-80 (1976); Albemarle Paper Co. v. Moody, 422 U.S. 405, 413 25 (1975).

${ }^{128}$ In considering requests for interim modifications of quotas, courts would presumably look to the relatively open-ended factors which they consider when minority employees seek interim relief in original actions: "the likelihood of prevailing on the merits, the existence of irreparable injury, the degree of harm to the defendant from the issuance and to the plaintiff from the denial of such injunctive relief, and the public interest." B. ScHLEI \& P. Grossman, supra note 119, at 1412-13.

${ }^{128}$ But see infra note 133.

130443 U.S. 193 (1979).

131 Id. at $208,198-99$.

132 Id. at 208. 
Although Weber involved a challenge to a quota adopted by an employer without any judicial involvement, its analysis also seems applicable to consent decrees, since in both situations the employer voluntarily agrees to establish quotas. ${ }^{133}$ Thus some lower courts which have been presented with proposed consent decrees that would establish quotas have relied on the Weber analysis in deciding whether to approve the decrees. For example, they have concluded that the quotas cannot "unnecessarily trammel" majority employees' interests in the ways suggested by the Weber opinion. ${ }^{134}$ They also have sought evidence that minority employees have suffered some discrimination or disadvantage, a requirement which is designed "to ensure that new forms of invidious discrimination are not approved in the guise of [race-conscious remedies]." "135 The amount of discrimination or disadvantage that must be shown is not entirely clear. It appears, however, that an "identifiable statistical disparity" between the actual composition of the employer's work force and the expected composition absent discrimination is a sufficient showing, even if it falls short of violating Title VII or some other law. ${ }^{136}$

13s In Weber, the fact that the quota was voluntarily adopted by the employer played a prominent role in the Court's analysis. See id. at 200, 205-08. Thus there would seem to be a sound basis for distinguishing voluntarily adopted quotas-whether adopted by the employer without action by a court, or established by a consent decree-from quotas that are imposed by a court after a trial on the merits of the minority employees' claims. See Firefighters Local Union No. 1784 v. Stotts, 467 U.S. 561, 104 S. Ct. 2576, 2605 n.9 (1984) (Blackmun, J., dissenting). However, Stotts can be read both as casting doubt on the validity of court-imposed quotas, and as implying that this doubt extends to quotas established by consent decrees. See id. at 2588-90; cf. id. at 2605 \& n.9, 2608-10 (Blackmun, J., dissenting). If that turns out to be correct, then the scope of majority employees' interests would be far broader than this comment suggests. That question may be answered by the Supreme Court when it reviews Vanguards of Cleveland v. City of Cleveland, 753 F.2d 479 (6th Cir. 1985) (applying Weber standards to determine whether a consent decree impermissibly infringes on majority employees' interests), cert. granted sub nom. Local Number 93, Int'1 Ass'n of Firefighters v. City of Cleveland, 106 S. Ct. 59 (1985) (No. 84-1999).

${ }^{134}$ See, e.g., City of Cleveland, 753 F.2d at 484-85, 489 n.10; Kirkland v. New York State Dep't of Correctional Servs., 711 F.2d 1117, 1132, 1135 (2d Cir. 1983), cert. denied, 465 U.S. 1005 (1984); Stotts v. Memphis Fire Dep't, 679 F.2d 541, 553 (6th Cir. 1982), rev'd on other grounds sub nom. Firefighters Local Union No. 1784 v. Stotts, 467 U.S. 561, 104 S. Ct. 2576 (1984).

${ }^{135}$ Kirkland, 711 F.2d at 1130 (quoting Setser v. Novack Inv. Co., 657 F.2d 962, 968 (8th Cir. 1981) (en banc)).

138 While some courts have approved quotas where the minority employees made out a prima facie case of discrimination, see, e.g., Kirkland, 711 F.2d at 1130 ("[A] showing of a prima facie case of employment discrimination through a statistical demonstration of disproportionate racial impact [is sufficient] to serve as a predicate for a voluntary compromise containing race conscious remedies."), others have held that an "identifiable statistical disparity" short of a prima facie case is sufficient, see, e.g., Stotts, 679 F.2d at 552-53 \& n.10; see also City of Cleveland, 753 F.2d at 484 ("A consent decree may not embody an affirma- 
This understanding of the substantive interests of majority employees provides a basis for limiting the role that majority employees can play in challenging quotas established by consent decrees. Majority employees should not be permitted to force a trial on the issue of whether their employer had in fact discriminated against minority employees in violation of Title VII or other law, ${ }^{137}$ since under Weber an employer need not have violated the law as a precondition for voluntarily adopting a quota. Rather, adversarial factfinding should be limited to the narrow question of whether there is an "identifiable statistical disparity" that is sufficient to support quotas. In addition to that factual challenge, majority employees should also be allowed to make legal arguments, such as that the quotas "unnecessarily trammel" their interests in the ways suggested by Weber.

Finally, the substantive interests that majority employees can assert, and the procedural opportunities which they are afforded to assert those interests, should not vary depending on whether the majority employees enter the dispute by intervention, by joinder, or by bringing a subsequent suit. Presently, there is potentially wide variation: there is some authority that implies that majority employees who are joined as parties to the original suit or who intervene in it can force a trial on the merits of the minority plaintiffs' claims; ${ }^{138}$ other cases suggest that majority employees' claims

tive action plan unless the employer has utilized minorities at a rate less than their proportion in the relevant labor market.").

${ }^{137}$ See, e.g., Kirkland, 711 F.2d at 1126-30 (where minority plaintiffs have made a showing of a prima facie case of disparate-impact discrimination, intervening majority employees cannot force a trial at which they would defend the "job-relatedness" of the discriminatory employment practice). One court has permitted a union, once joined, to force minority employees to prove their claims at trial. See United States v. City of Miami, 664 F.2d 435 (5th Cir. 1981) (en banc); see also Culbreath v. Dukakis, 630 F.2d 15, 22 (1st Cir. 1980) (in denying unions' motions to intervene in the original suit, court observed that "there is a distinct probability that the intervention of the unions will destroy the consent decree and force a trial on the merits"). While the court in City of Miami emphasized that the proposed quotas would violate the majority employees' collective bargaining agreement, the logic of the court's opinion could be extended to cover situations where no collective bargaining agreement was involved and the majority employees were raising only Title VII or other discrimination claims. See 664 F.2d at 447 (Rubin, J., concurring) ("A party potentially prejudiced by a decree has a right to a judicial determination of the merits of its objection. . . . Those who seek affirmative remedial goals that would adversely affect other parties must demonstrate the propriety of such relief."). But see Kirkland, 711 F.2d at 1127 (City of Miami's analysis is limited to situations where majority employees' contractual rights are implicated). The holding of City of Miami has been sharply criticized. See $2 \mathrm{~A}$. LARSON \& L. LARSON, EMPloyment Discrimination $\$ 56.32$ (1985).

${ }^{138}$ See supra note 137 (discussing City of Miami and Culbreath). 
can be considered under ad hoc procedures; ${ }^{139}$ and still other courts suggest that if majority employees are allowed to bring subsequent suits, then the range of substantive issues which could be raised in such suits is even narrower than Weber would allow. ${ }^{140}$ These differing approaches misconstrue the nature of majority employees' interests, and provide the original parties with powerful incentives to keep majority employees out of the original suit. The better approach is to recognize that majority employees can make the limited claims suggested by the Weber opinion, and to consider those claims in the same manner as any other claims brought in federal court. ${ }^{141}$

139 The most extreme view, that it is sufficient for nonparty majority employees to be offered an opportunity to participate in a "fairness hearing" where they are allowed to voice objections to a proposed decree, was apparently taken by the Ninth Circuit in Dennison. See supra notes 50,51 . Under that approach, majority employees remain nonparties and apparently would be unable to appeal the trial court's entry of the decree. One commentator has advocated a more formal approach under which majority employees would be "granted limited intervention" in the original suit; the trial court, before entering the decree, would hold a fairness hearing and thereby develop a "record . . . articulat[ing] the statistical evidence of discrimination"; the trial court would be required to "explain whatever action it takes"; majority employees could appeal that action; and, appellate review would be somewhat less deferential than it is now. Schwarzschild, supra note 25, at 929-34. Some courts appear to utilize something like the Schwarzschild approach. See, e.g., City of Cleveland, 753 F.2d at 482 (district court entered consent decree after it "held an evidentiary hearing to consider the [intervening union's] objections"); Kirkland, 711 F.2d at 1124 (court held hearings to consider intervening majority employees' objections). However, it is difficult to tell exactly what procedures were followed in those cases, and there is reason to think that the majority employees may not have been afforded the full range of procedural protections which usually apply to a party bringing a claim in federal court. For example, in City of Cleveland the district court "issued no findings of fact or conclusions of law. None of the procedures generally required by due process was followed." Brief for the United States as Amicus Curiae at 25-26, Local Number 93, Int'l Ass'n of Firefighters v. City of Cleveland, cert. granted, $106 \mathrm{~S}$. Ct. 59 (1985) (No. 84-1999).

140 In EEOC v. McCall Printing Corp., 633 F.2d 1232 (6th Cir. 1980), black employees challenged a consent decree granting retroactive seniority to female employees. The court held that "conciliation agreements resulting in consent decrees may not be considered independent acts of discrimination, as a matter of law, [absent] allegations of bad faith [which suggest that] the agreement was not a bona fide attempt to conciliate a claim but rather an attempt to bestow unequal employment benefits under the guise of remedying discrimination." Id. at 1238. The McCall court did not explain what would constitute a "bona fide attempt," though the implication would seem to be that a decree which establishes quotas and fails to meet the requirements of Weber could nonetheless be a "bona fide attempt." If so, then this comment rejects the McCall standard. Rather, majority employees who are forced to bring a subsequent suit should be entitled to claim that the Weber requirements have not been met; if those claims are substantiated, the quotas should be modified or eliminated prospectively. See supra notes 127-28 (discussing remedies).

142 If district courts adhere to established procedural rules when considering majority employees' claims, it does not necessarily follow that majority employees will be able to force a trial in every case. As with any claimant in the federal courts, majority employees will be vulnerable to motions for summary judgment under rule 56(b) of the Federal Rules 


\section{Conclusion}

Courts have struggled to find the proper role for majority employees in employment discrimination lawsuits brought by their minority colleagues. The courts' instinct is that employment discrimination suits should be resolved in a single proceeding. While that instinct is probably correct, many courts have chosen an improper means to implement it: they have dismissed subsequent suits whether or not any basis exists for doing so under principles of res judicata or comity.

While such disputes strain the limits of established principles of civil procedure and due process, they need not break those limits. A partial solution is for courts to be more liberal in allowing majority employees to intervene in the original action, as well as permitting the joinder of majority employees when one of the original parties requests it. Beyond that, courts must develop a more precise understanding of majority employees' substantive interests in order to tailor the procedural role which majority employees can play. Finally, that role should be the same whether majority employees intervene in the original suit, are joined as parties to that suit, or are forced to bring a subsequent suit.

Mark E. Recktenwald 